\title{
Hydrometeorological Analysis of the 29 August 2003 Flash Flood in the Eastern Italian Alps
}

\author{
Marco Borga, Paolo Boscolo, Francesco Zanon, and Marco Sangati \\ Department of Land and Agroforest Environment, University of Padua, Padua, Italy
}

(Manuscript received 9 June 2006, in final form 16 November 2006)

\begin{abstract}
The 29 August 2003 storm on the upper Tagliamento River basin in the eastern Italian Alps is examined as a prototype for organized convective systems that dominate the upper tail of the precipitation frequency distribution and are likely responsible for the majority of flash flood peaks in this area. The availability of high-resolution rainfall estimates from radar observations and rain gauge networks, together with flood response observations derived from stream gauge data and post-event surveys, provides the opportunity to study the hydrometeorological and hydrological mechanisms associated with this extreme storm and the associated flood. The flood occurred at the end of a climatic anomaly of prolonged drought and warm conditions over Europe and the Mediterranean region. A characteristic of the event is its organization in well-defined banded structures, some of which persisted in the same locations for the duration of the event. The steadiness of these rainbands led to highly variable precipitation accumulations and, associated with orographic enhancement, played a central role in the space-time organization of the storm. Two dominant controls on extreme flood response are recognized and analyzed: steadiness of convective bands and dry antecedent soil moisture conditions.
\end{abstract}

\section{Introduction}

The eastern Italian Alps (Fig. 1) in the Friuli region of Italy has been a workshop for hydrologists and geomorphologists to study the hydrological and geomorphological effects of extreme storms (Deganutti et al. 2000; Marchi et al. 2002; Marchi and D'Agostino 2004). The region includes the upper Tagliamento River basin as the major river system and is characterized by frequent heavy precipitation. Daily rainfall amounts exceeding $500 \mathrm{~mm}$ may be locally recorded in this area in a 20-30-yr time span (Villi et al. 1986; Ceschia et al. 1991). During late fall, winter, and spring, heavy precipitations are normally related to synoptic circulations and to southerly humid flows. During summer and partially during fall, the contribution from convective or mesoscale rainfall becomes significant or even prevailing. Because of the rugged topography of the region, together with its densely fractured bedrock and its high seismicity (Querini 1977), heavy convective pre-

Corresponding author address: Marco Borga, Department of Land and Agroforest Environments, AGRIPOLIS, University of Padova, via dell'Università, 16 Legnaro, IT-35020, Padua, Italy. E-mail: marco.borga@unipd.it cipitations result often in flash floods, associated with diffused landsliding, debris flows, and sediment transport.

On 29 August 2003, at the end of a prolonged drought, a mesoscale convective system affected the study area, starting at 1000 local standard time (LST) and lasting for approximately $12 \mathrm{~h}$. Prior to the development of convection, the atmosphere was characterized by strong instability as evidenced by the very high CAPE value on the Udine radio sounding of 29 August 2003 at 0700 LST (about $4000 \mathrm{~J} \mathrm{~kg}^{-1}$ for the CAPE computed based on the most unstable parcel). Precipitable water computed for this radio sounding amounts to $44 \mathrm{~mm}$ and shows that the humidity content of the atmosphere was already high. The storm affected a $1500-\mathrm{km}^{2}$ area, and caused loss of lives and substantial disruption of the local economy, with damages close to 1 billion euro (Tropeano et al. 2004).

Radar rainfall observations, combined with data from 15 rain gauges, provide high temporal $(5 \mathrm{~min})$ and spatial $\left(1 \mathrm{~km}^{2}\right)$ representation of rainfall from the August 2003 storm. A noticeable characteristic of the precipitation event was its organization in well-defined banded structures. The steadiness of these rainbands led to highly variable precipitation accumulations.

DOI: $10.1175 / J H M 593.1$

(C) 2007 American Meteorological Society 


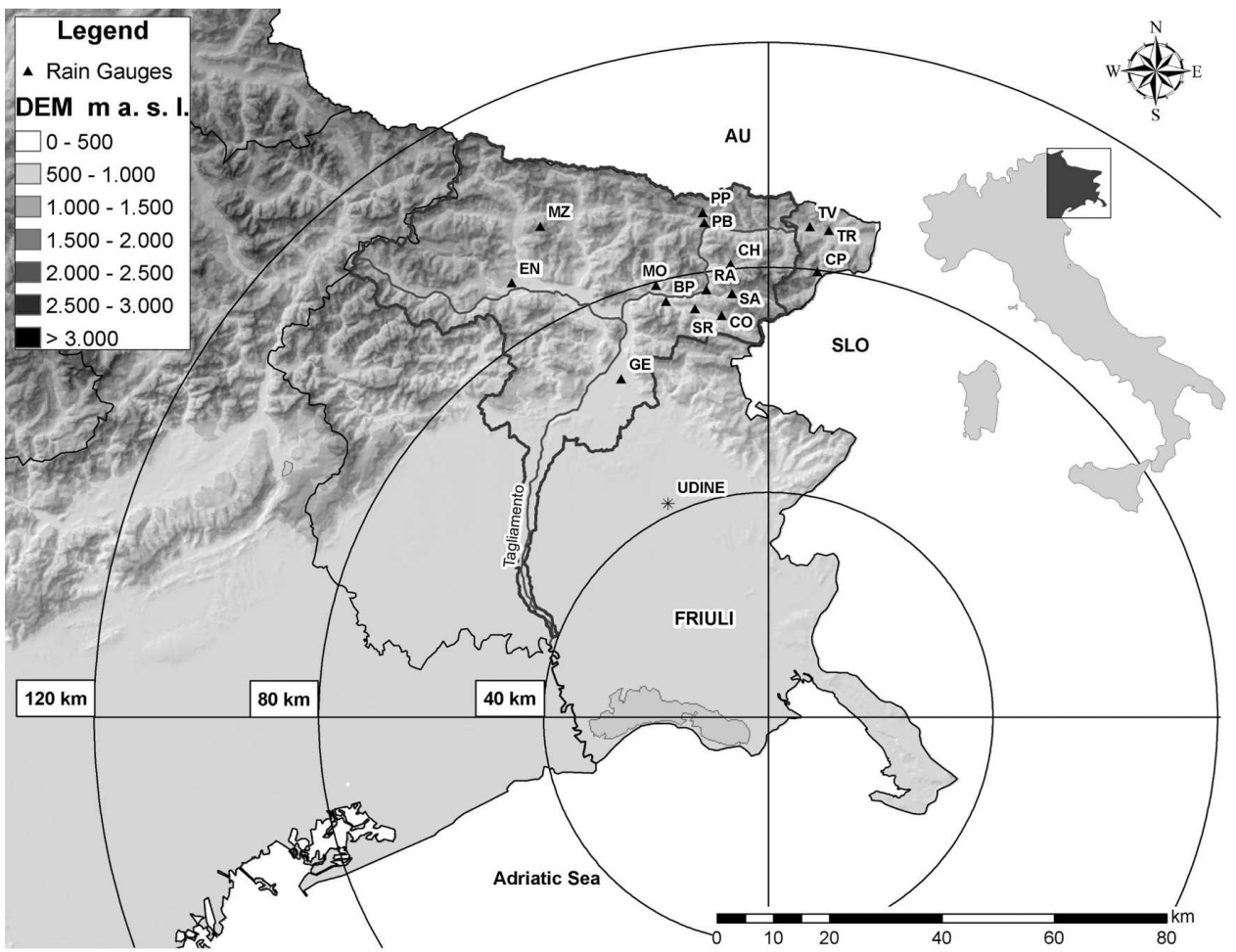

FIG. 1. Location of the OSMER radar and the Tagliamento River basin with digital terrain model (DTM) of northeastern Italy. The locations of the rain gauge stations used in the study are also reported.

Time series of river stage at a number of gauging stations were combined with indirect discharge measurements to produce flood hydrographs at several river sections. Extensive post-event surveys of peak flows and interviews were carried out to characterize the spatial variability of flood response.

The 29 August 2003 flood is also of particular interest because it provides an end member in the spectrum of impacts of antecedent soil moisture on extreme floods. The event resulted indeed as a combination of two extreme events, since very large accumulations of rainfall over 3-6 h occurred at the end of a climatic anomaly of prolonged drought and warm conditions in Europe and over the Mediterranean. Analysis of temperature records over Europe shows that the 3-month period June-August 2003 has been probably the warmest since 1500 over western Europe (Casty et al. 2005). The drought culminated in August, but precipitation accumulations were below average since the beginning of the year. At the Udine rain gauge station, close to the study area, the cumulative precipitation total for the first eight months of 2003 was around $50 \%$ of the climatological average. As a consequence, the soil water content was very low at the beginning of the event. A heavy localized thunderstorm that occurred the day before the flood on a portion of the Fella River system introduced elements of spatial variability in the pattern of soil moisture initial conditions.

Whereas it is generally recognized that antecedent soil moisture is of little importance in determining the magnitude of extreme floods (Wood et al. 1990), the August 2003 flood provides a counterexample of the possible role of low antecedent soil moisture conditions, when combined with high soil moisture capacity, on the flood response of extreme storms. This impact is in terms of enhanced nonlinearity, that is, nonlinear variation of runoff with storm total, and mitigation of flood peak magnitude with respect to rainfall magnitude. Large initial losses and nonlinearities related to the wetting-up processes and to the extension of the river network to unchannelized topographic elements are examined in this study.

In line with previously published flash flood monographs (e.g., Smith et al. 1996; Ogden et al. 2000; Gaume et al. 2003, 2004; Delrieu et al. 2005; Hicks et al. 2005), this paper aims at documenting the 29 August 2003 flash flood. The objectives of this study are as follows:

(i) to identify the aspects of storm structure, motion, and evolution that control the spatial and temporal distribution of extreme rainfall and flooding; 
(ii) to provide estimates of peak discharge and to examine how peak discharge varied with basin scale;

(iii) to analyze the impact of space-time precipitation variability and of antecedent soil moisture conditions on flood response.

\section{Study region and data}

The region considered in this study (Fig. 1) includes a portion of the central chain of eastern Alps and of the Alpine foreland region. The arc-shaped mountainous range of the eastern Alps constitutes the major topographic feature within the analysis domain. The most prominent valleys are aligned along the main ridge in the west-east direction for some tens of kilometers. The area is included within the Friuli-Venezia Giulia region, which borders to the north with Austria, to the east with Slovenia, and to the west with Veneto. The region is characterized by three distinct pluviometric regimes: (i) the upper plain area, with mean annual precipitation (MAP) ranging from 1200 to $1500 \mathrm{~mm}$; (ii) the Alpine foreland area, where MAP locally increases up to $3300 \mathrm{~mm}$, which represents the highest mean values for the Alps; (iii) the inner Alpine area, where MAP decreases to $1600-1800 \mathrm{~mm}$, due to rain shadow effect of the southern ridges.

A description of the climatology of extreme subdaily rainfall is provided by the maps of the point average values of annual precipitation maxima (APM) for duration of 1, 3, and $6 \mathrm{~h}$ (Fig. 2). These maps are computed based on annual maxima from 36 stations, with an average usable record length of $39.5 \mathrm{yr}$. The maps show clearly (i) the relatively high values of these rainfall accumulations, and (ii) the orographic control on the spatial distribution of the average values. It is interesting to note that the highest values for 6-h duration are located on the Alpine foreland area, while for 1-h duration high values are also found on the southeastern coastal plain. The maps reveal also a marked decrease of the average APM values (for all durations) in the inner Alpine region.

The 29 August 2003 storm on the upper Tagliamento River basin is examined here as a prototype for organized convective systems that are likely responsible for the majority of flash flood peaks in this area of the eastern Italian Alps. Previous similar flash flood events occurred in this region on 22 June 1996 and on 11 September 1983. Figures 3a-c show the APM empirical regional growth curves based on APL plotting position (Stedinger et al. 1992) for the three durations of 3,6, and $12 \mathrm{~h}$. The data are obtained from 11 rain gauge stations located in the area of the Fella basin. It is interesting to note in these figures that all the normalized

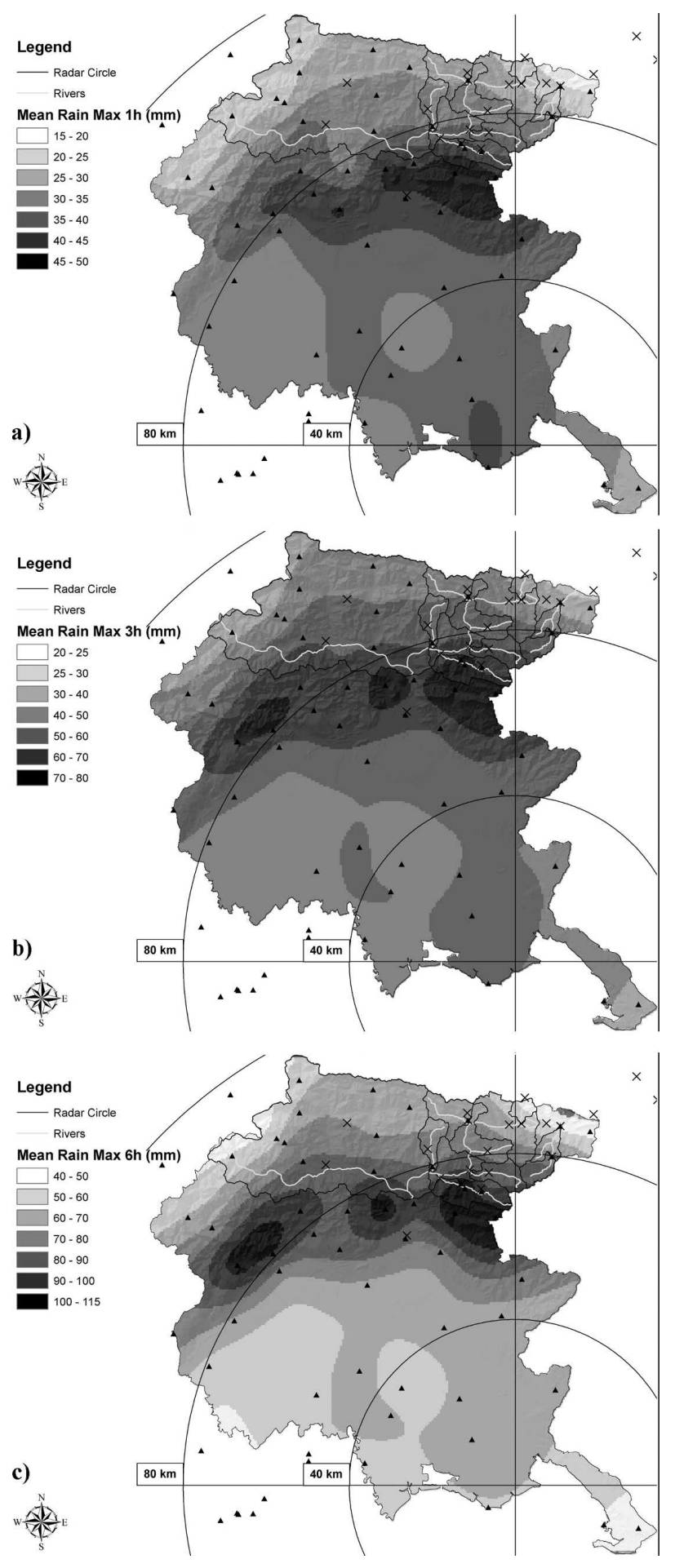

FIG. 2. Maps of point average of maximum yearly rainfall for durations of (a) 1, (b) 3, and (c) $6 \mathrm{~h}$, for the Friuli region. Triangles represent the position of the stations used to draw the maps. 

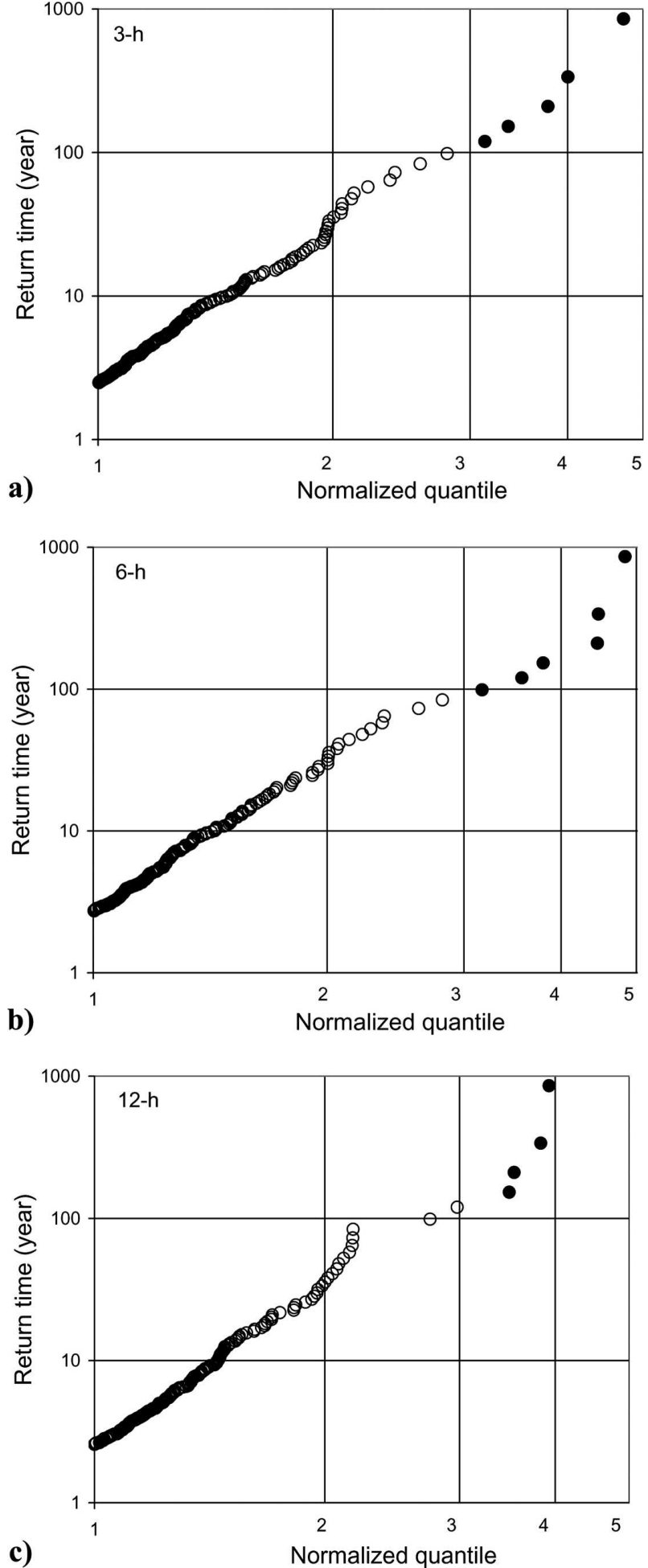

FIG. 3. Empirical regional growth curves of precipitation annual maxima for the three durations of (a) 1, (b) 6, and (c) $12 \mathrm{~h}$. Quantiles marked in bold result from the storms of 29 Aug 2003, 22 Jun 1996, and 11 Sep 1983. quantiles exceeding a value of 3.0 resulted from the aforementioned storms, which dominate therefore the upper tail of the precipitation frequency distribution.

The Tagliamento is the dominant river system in the analysis domain. From north to south (a linear distance of $<100 \mathrm{~km}$ ), the Tagliamento traverses four major regions: (i) the Julian and Carnian Alps, (ii) Alpine foreland area, (iii) the upper and lower Friulian plain, and (iv) the coast (Fig. 1). The alpine area of Friuli mainly consists of limestone, with a spatial sequence of Silurian, Devonian, Triassic, Jurassic, and Cretaceous formations north to south (Cucchi et al. 2000). Some portions of the regions are characterized by karstified limestone. The catchment is tectonically active, continuously developing faults and overthrusts. Many tributary streams, like the Fella, have sharp bends following the direction of these faults (Fig. 4). The prealpine mountains mainly consist of limestone (JurassicCenozoic) and Flysch (calcareous flysch, molasse) (Ward et al. 1999).

The Tagliamento is characterized by a flashy pluvionival flow regime, with the highest average discharges in spring (snowmelt runoff) and autumn (rainy period). At Pioverno (catchment area around $1866 \mathrm{~km}^{2}$ ) the average annual precipitation amounts to $2150 \mathrm{~mm}$ and average discharge is $91 \mathrm{~m}^{3} \mathrm{~s}^{-1}$. The August 2003 flood focused on the $705-\mathrm{km}^{2}$ Fella basin (Fig. 4), which is a major left-hand tributary of the Tagliamento River system. This basin has a mean altitude of $1140 \mathrm{~m}$ above sea level (ASL), with an average annual precipitation of 1920 mm. Major subbasins of the Fella River are Pontebbana $\left(70 \mathrm{~km}^{2}\right)$ and Aupa $\left(50 \mathrm{~km}^{2}\right)$ (right-hand tributaries) and Dogna $\left(47 \mathrm{~km}^{2}\right)$, Raccolana $\left(63 \mathrm{~km}^{2}\right)$, and Resia $\left(107 \mathrm{~km}^{2}\right)$ (left-hand tributaries). In the Fella watershed, the main carbonate complexes influenced by karst phenomenon are located around Monte Canin, in the upper Resia and Raccolana basins.

During the August 2003 flood, exceptional rainfall rates and accumulations were observed on the righthand tributaries of the Fella, whereas the left-hand tributaries received much less rainfall, imposing a contrasting flood response to the different elements of the river system. On 28 August 2003, the day before the flood, a localized convective storm generated almost $100 \mathrm{~mm}$ of precipitation on areas of the left-hand tributaries of the Fella River system. This added to the various nonlinearities sources in the hydrologic response, introducing elements of spatial variability in the pattern of antecedent soil moisture conditions.

Postflood surveys were important source information for the flood analysis. Surveys were concentrated in the upper Fella basin and included (i) collection of rainfall data, (ii) indirect peak flood estimation, (iii) mapping 


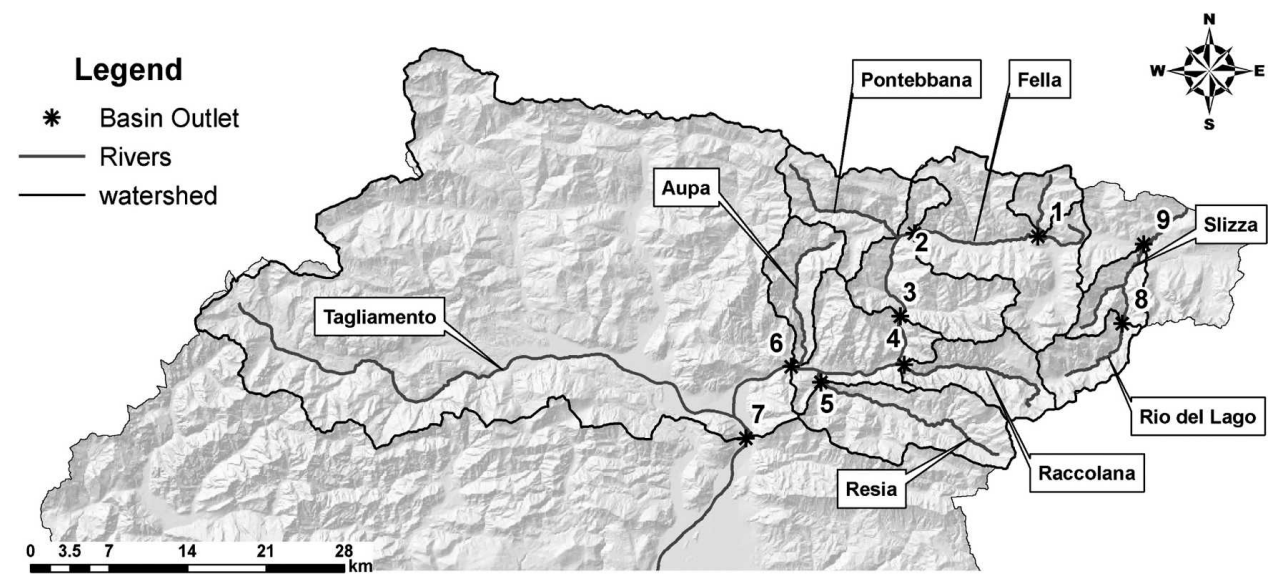

FIG. 4. Catchment map of the upper Tagliamento River basin, with subcatchments of the Fella River basin: 1) Uqua at Ugovizza; 2) Fella at Pontebba; 3) Fella at Dogna; 4) Raccolana at Raccolana; 5) Resia at Borgo Povici; 6) Fella at Moggio Udinese; 7) Tagliamento at Venzone; 8) Rio del Lago at Cave del Predil; 9) Slizza at Tarvisio.

of geomorphic effects, (iv) collection of hydraulic saturated conductivity values in a number of sites, and (v) postflood interviews.

\section{Rainfall data collection and elaboration}

Radar and rain gauge observations are used to derive rainfall fields for the August 2003 storm. Five-minute rain gauge data were collected at 15 rain gauges (Fig. 1), whereas storm total rainfall was available at six additional daily rain gauges. Twelve out of the 15 rain gauges are located within the Fella watershed closed at Moggio Udinese $\left(623 \mathrm{~km}^{2}\right)$ and the nearby Slizza watershed $\left(73.1 \mathrm{~km}^{2}\right)$, that is, an average density of about one rain gauge per $50 \mathrm{~km}^{2}$. Note that the network density is not homogeneous and that some gaps are evident in the northwest part of the Fella basin.

Volume scan reflectivity data from the Doppler, dual-polarized C-band OSMER radar station, located at Fossalon di Grado (Fig. 1) (time resolution of $5 \mathrm{~min}$ and spatial resolution of $250 \mathrm{~m}$ in range by $0.9^{\circ}$ in azimuth), were used to derive radar rainfall rates. The radar measures the reflectivity in two orthogonal (horizontal and vertical) polarizations, $Z_{h}$ and $Z_{v}$, respectively. When the two reflectivities are measured in an approximately simultaneous fashion, the differential reflectivity (in decibels) can be derived by $\mathrm{dB} Z_{\mathrm{DR}}=10$ $\log _{10}\left(Z_{H} / Z_{V}\right)$. In this study, rainfall rates were estimated based on horizontal-polarized observations; $Z_{\mathrm{DR}}$ values were use to discriminate ground clutter from rainfall observations. Analysis based on rainfall rates derived by using $Z_{\mathrm{DR}}$ observations are reported by Borga and Zanon (2006, manuscript submitted to $J$. Hydrol., hereafter BZ06).
A number of procedures were applied to the reflectivity data to correct for the following error sources: (i) ground clutter; (ii) partial beam occlusion; (iii) path attenuation; and (iv) wind drift. These procedures are described in detail by BZ06; a summary is provided below. Hail was not observed during the event, so no correction was implemented to remove hail contamination.

An algorithm based on a three-step decision tree, based on Doppler velocity, clear-air echo statistics, and $Z_{\mathrm{DR}}$ variance, was used to flag clutter-contaminated data in the polar volumes (Bechini et al. 2002). Correction for beam occlusion is based on offline computation of the percentage of beam power intercepted by the orography by using a model of beam propagation and a digital description of the orography (Borga et al. 2000; Pellarin et al. 2002). Path attenuation due to precipitation (which can generate large errors at $\mathrm{C}$ band at high rainfall rates; Delrieu et al. 2000) is corrected by using a variational method with gauge accumulations as external constraints and the Hitschfel-Bordan (1954) equation as model (Berenguer et al. 2002).

Wind drift was a major error source in the comparison of radar estimates to rain gauge measurements, due to the strong winds and to the sharp local differences in rainfall accumulation. Wind drift correction was carried out by taking into account horizontal wind velocity and drops' fall time to compute the rainfall advection. We adopted a bulk-advection approach, by assuming the same fall speed for all drops in a radar pixel.

Rainfall estimation was based on reflectivity observations from the $2.06^{\circ}$ beam elevation, which is the lowest elevation affected by minimal beam occlusion over the study area. Effects due to nonuniform reflec- 
Elevation 2.06 degrees $1 \mathrm{~h}$ accum ulations

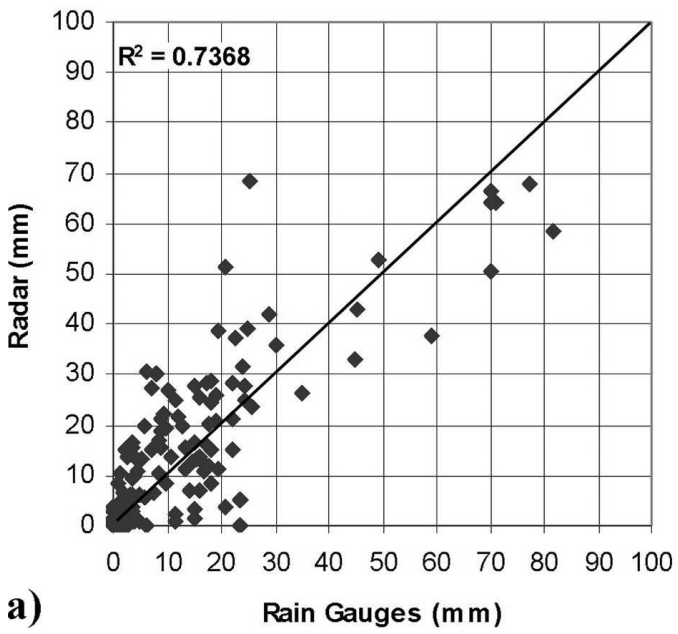

Elevation 2.06 degrees $12 \mathrm{~h}$ accum ulations

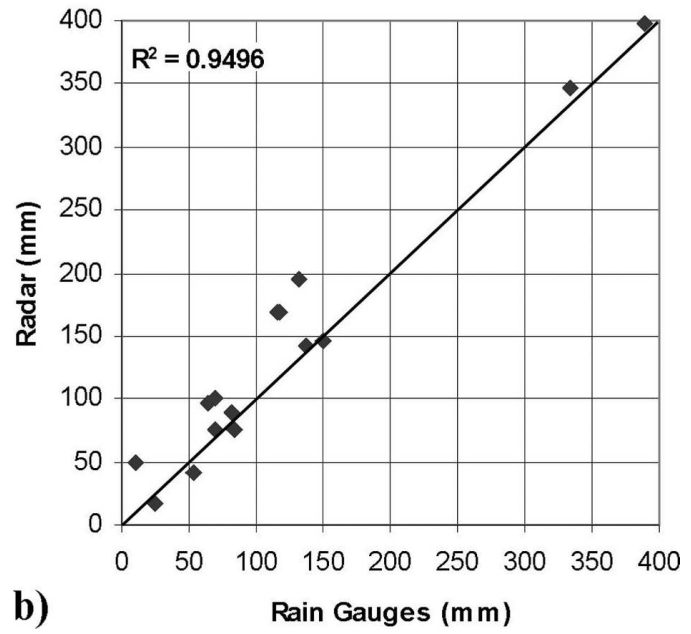

FIG. 5. Scatterplot of radar estimates and rain gauge accumulations at (a) hourly time steps and (b) 12-h time steps.

tivity along the vertical were not included in the analysis and correction procedure, due to the difficulties of separating the effects of attenuation from those generated by vertical variability of reflectivity and of beam occlusion for localized storms. After correction, the reflectivity factor $Z$ was converted to rainfall rate $R$ through an empirical $R-Z$ power function of the form

$$
R=a Z^{b} .
$$

The $R-Z$ parameters used are $a=0.022$ and $b=0.67$ for $R$ in $\mathrm{mm} \mathrm{h}^{-1}$ and $Z$ in $\mathrm{mm}^{6} \mathrm{~m}^{-3}$. These parameter values are used in this region for estimation of convective events and are similar to those used in the so-called Next Generation Weather Radar (NEXRAD) convective relationship (Ogden et al. 2000).

Figures $5 \mathrm{a}$ and $5 \mathrm{~b}$ show the scatterplot between the 15 rain gauges' rain measures and the corresponding radar estimates. The plot shows a general good agreement; the squared correlation coefficient for hourly accumulation is 0.73 , while for rainfall accumulation on 12 $\mathrm{h}$ it raises to 0.94 . The radar estimates are generally positively biased, with an overestimation around $10 \%$. A few hourly rates are strongly overestimated by radar. It is difficult to identify clearly the origins of these differences, even though some of them are related to a less-than-optimal correction for attenuation (BZ06). Of particular importance is the capability of radar to delineate heavy rainfall areas. Figure 6 summarizes the results obtained over a region centered on the Fella basin by intercomparing gridded gauge accumulations (obtained by using the spline technique) with radar es- timates in terms of exceedance areas, that is, the areas over which a given amount of rainfall was exceeded in the region of interest. From the gauge network one infers that the area exceeding $350 \mathrm{~mm}$ is around $12 \mathrm{~km}^{2}$, in contrast to a radar derived value of $55 \mathrm{~km}^{2}$. The accuracy of storm total radar rainfall accumulations was confirmed by comparison with values from daily rain gauges (BZ06).

\section{Precipitation analyses}

Precipitation was analyzed by using animations of both the instantaneous rain rates at the 5-min time steps and the cumulated rain amounts over a given pe-

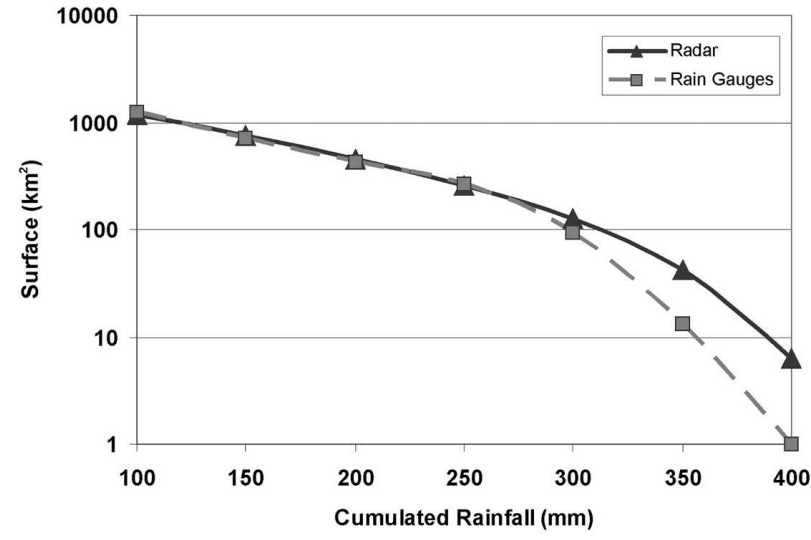

FIG. 6. Curves of exceedance areas, i.e., the areas over which various rain thresholds were exceeded, using gridded rain gaugebased interpolation and radar-based estimates. 


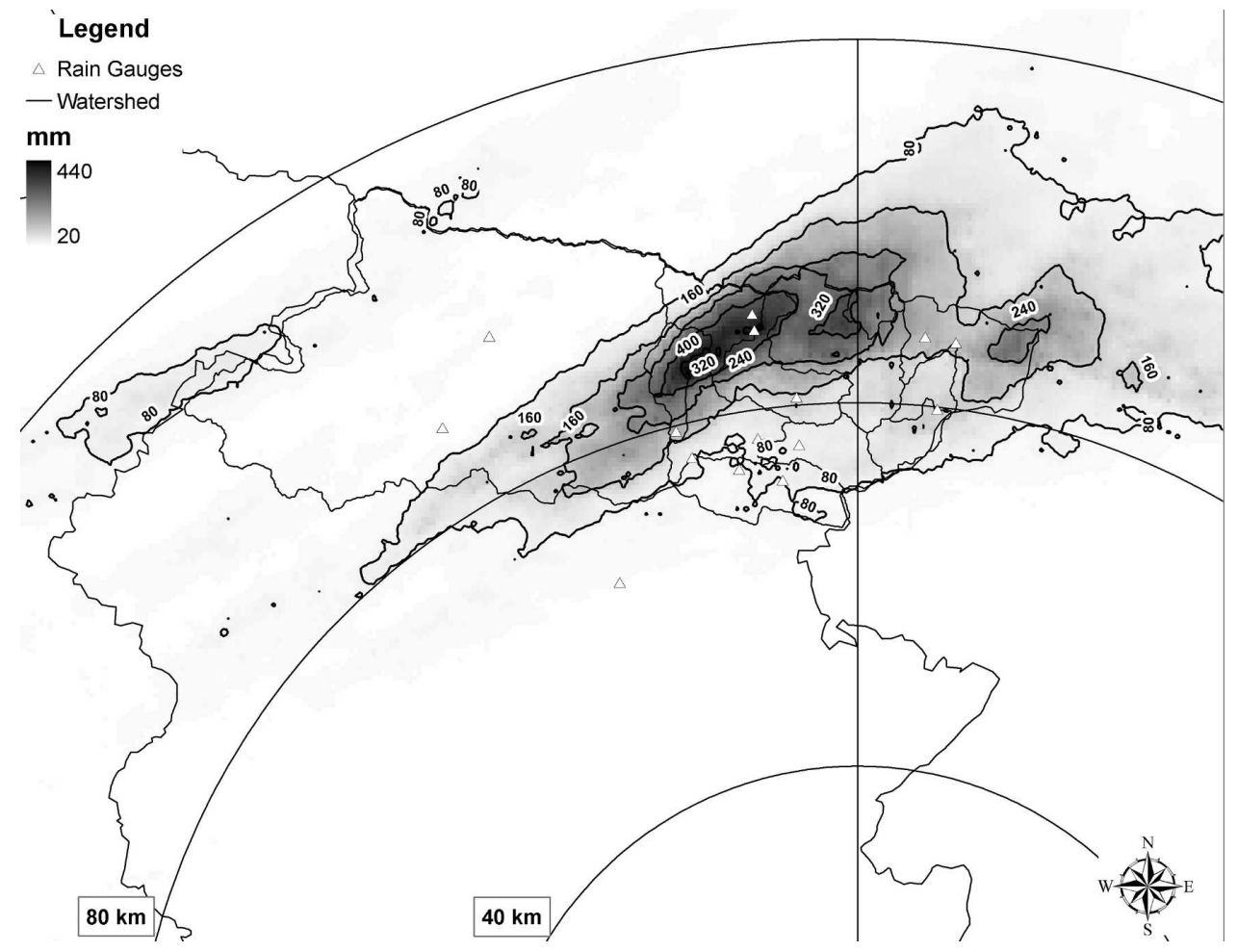

FIG. 7. Storm total rainfall (mm) for the 29 Aug 2003 event.

riod. A synthesis of this information is provided by the following four figures: Fig. 7, which provides the storm total precipitation; Fig. 8, which reports the rain amounts during three main phases of the event; Fig. 9, which reports tracking-based representations of rainfall cells motion; and Fig. 10, which illustrates the spatial patterns of local maximum rainfall accumulations for 1 and $6 \mathrm{~h}$.

The storm total precipitation (Fig. 7) exhibits three local peaks of rainfall accumulations exceeding 320 $\mathrm{mm}$. The most extended accumulation is over the upper Aupa basin and the mid-Pontebbana basin; the second peak is close to the Uqua basin and near the ItalianAustrian border; the third one (and also the less extended) is located over the extreme eastern portion of the study area. The storm total rainfall distribution reflects southwest-northeast motion of the storm elements and west-east shift of the tracks of the storms. This evolution can be distinguished in Fig. 8, with the storm accumulation in three phases.

In the initial period (1000-1300 LST) the rainfall maxima (60-70 $\mathrm{mm}$ ) extended over an elongated region at the western periphery of the Tagliamento, close to the Veneto-Friuli border. A secondary rainfall accumulation maximum extends over the right-hand tributaries of the Fella, from Aupa to Uqua, and over part of the Resia.
In the second period (1300-1900 LST) an explosive growth of precipitation can be recognized over the right-hand tributaries of the Fella River system, associated with orographic enhancement. A maximum of $350 \mathrm{~mm}$ is identified over the region comprised between Pontebbana and Uqua. Because of the west-east shift of storm tracks, precipitation extends also to the left-hand Fella tributaries, with accumulation up to $70 \mathrm{~mm}$.

In the last phase (1900-2200 LST) the precipitation accumulation splits in three regions, with maximum of precipitation still concentrated over the Aupa and a less organized precipitation focused over the Slizza River system, at the eastern border of the Tagliamento River basin.

A striking characteristic of the event is its organization in four well-defined banded structures. The bands can be distinguished in Fig. 10a, which reports the maximum hourly values throughout the storm event. Some of the bands persisted in the same locations for the duration of the event, as evidenced in Fig. 8. The steadiness of these rainbands led to highly variable precipitation accumulations with extreme spatial gradients up to $70 \mathrm{~mm} \mathrm{~km}^{-1}$.

The spatial organization of the bands of the August 2003 storm was analyzed based on the instantaneous reflectivity observations. Mean band alignment, mea- 


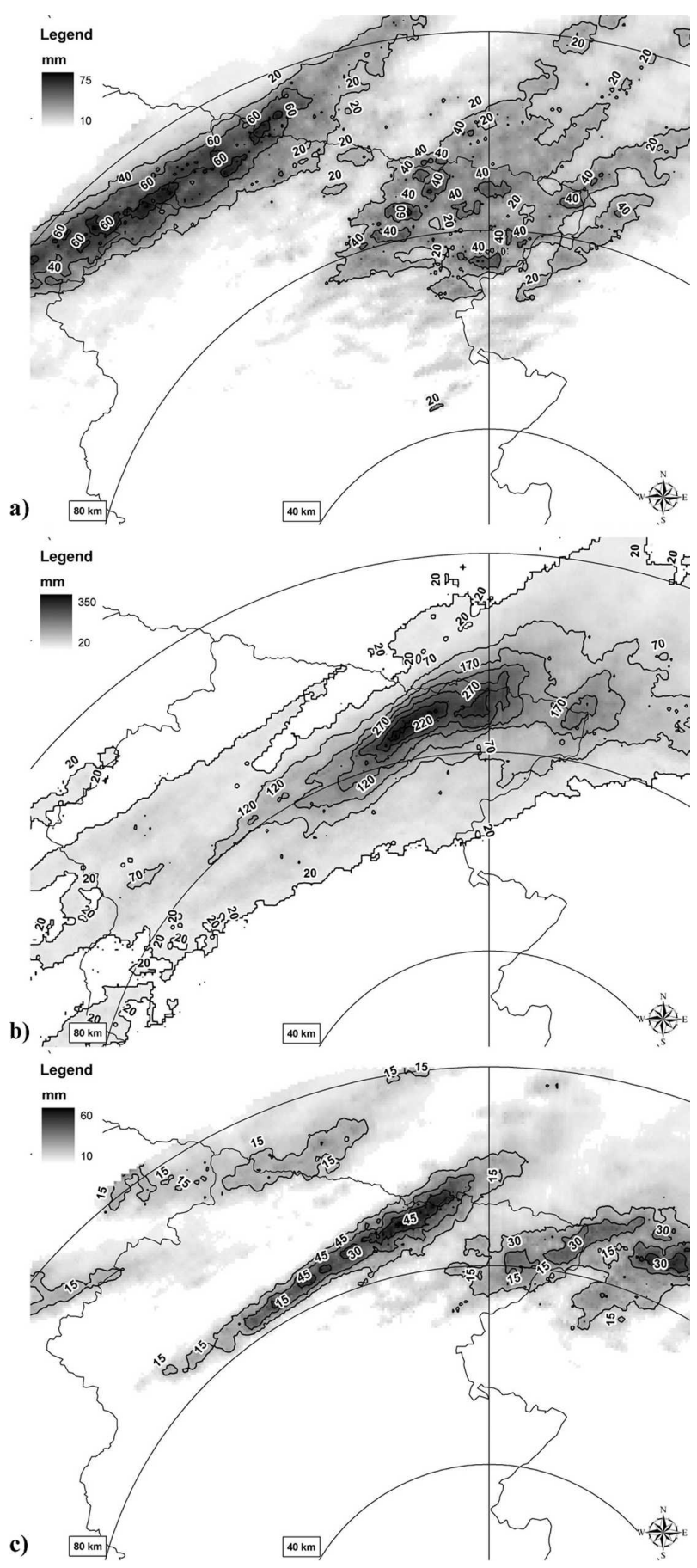

FIG. 8. Rain accumulations (mm) for three phases of the 29 Aug 2003 storm: (a) 1000-1300, (b) 1300-1900, (c) 1900-2200 LST.

sured counterclockwise relative to the east, is comprised between $30^{\circ}$ and $35^{\circ}$, and is almost parallel to the orographic flanks of the Veneto region (Fig. 1). Mean width, defined as distance between 5-dBZ contours on the flanks of individual precipitation bands, is around 9 $\mathrm{km}$. Mean spacing, that is, distance between adjacent

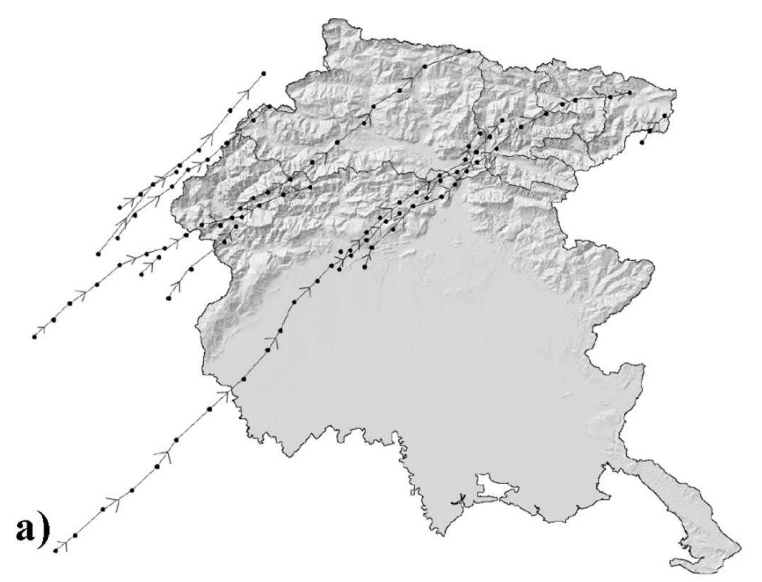

b)

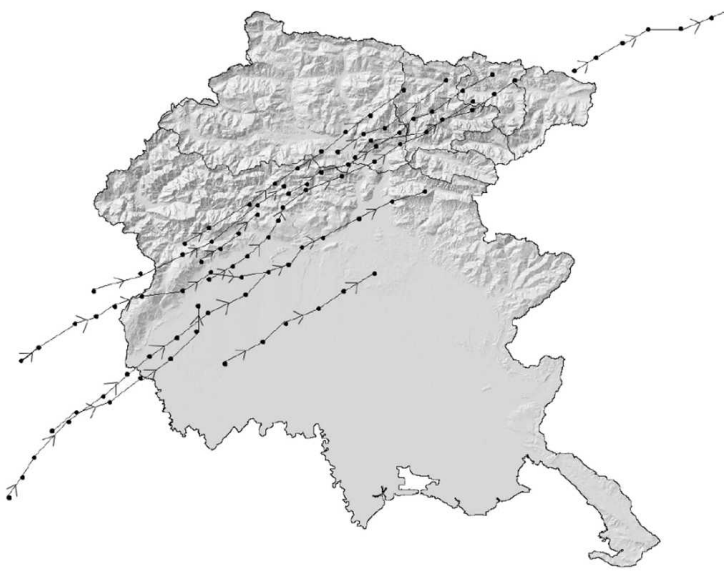

c)

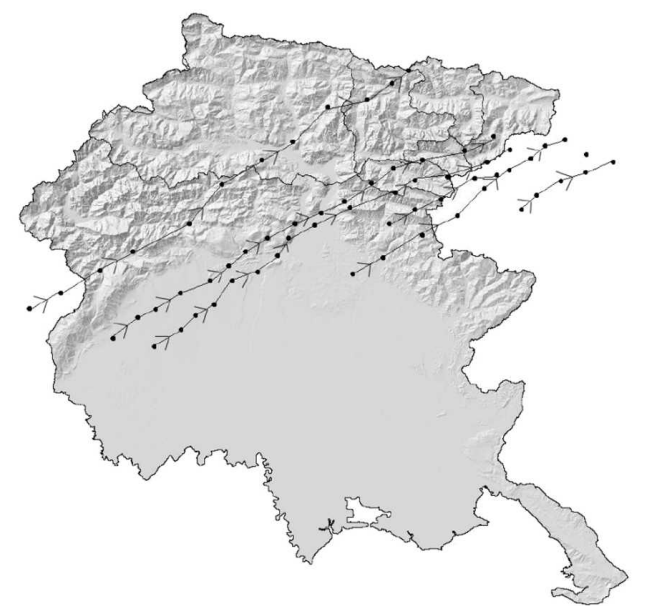

FIG. 9. Tracks of the rainfall cells for the 29 Aug 2003 storm:

(a) 1300-1500, (b) 1500-1700, and (c) 1700-1900 LST.

bands, measures $13 \mathrm{~km}$. Although some of the bands appear to form over and downstream of small-scale peaks on the gradually sloping barrier, others form past valleys or have no clear connection to obvious smallscale topographic features.

The patterns of the maximum precipitation for 1 and $6 \mathrm{~h}$ (Figs. 10a,b) show clearly that on all four bands 


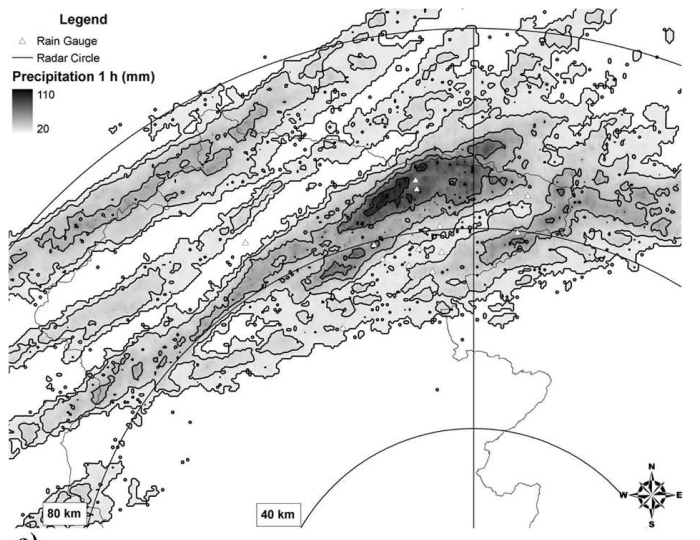

a)

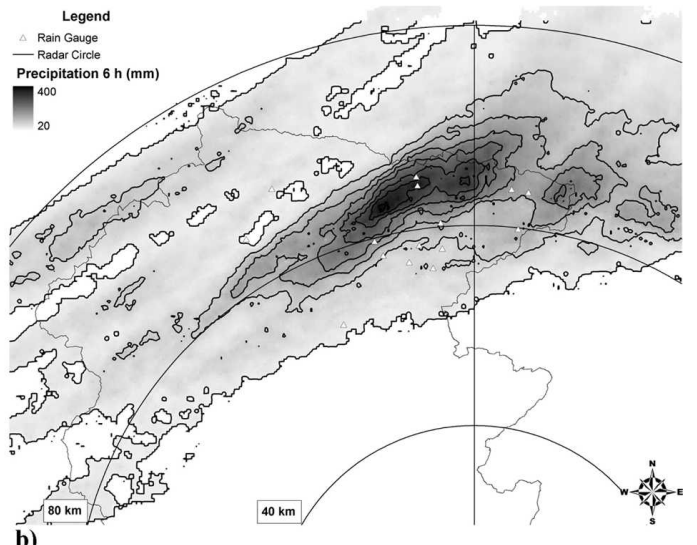

FIG. 10. Analysis of rainfall maxima: spatial patterns for rainfall maxima over (a) $1 \mathrm{~h}$, with contour intervals equal to $20 \mathrm{~mm}$ and (b) $6 \mathrm{~h}$, with contour intervals equal to $50 \mathrm{~mm}$.

precipitation reached local hourly rates exceeding 40 $\mathrm{mm}$, but only the central band [passing over Pontebba (PB in Fig. 1) and Pramollo (PP) rain gauge stations] lasted in a quasi-stationary way to give accumulations exceeding $400 \mathrm{~mm}$ in $6 \mathrm{~h}$.

The tracks of the convective cells through the region have been objectively identified by using the procedure developed by Bacchi et al. (1996); the tracks are reported in Fig. 9 for three different periods of the most intense phase of the storm (1300-1900 LST). The motion vector reported for each cell is obtained from cell locations computed for each volume scan. New cells formed repeatedly over the foothills of the Alps and intensified while being lifted onto the orographic barrier; this caused the quasi-stationary and persistent banded pattern. Direction and velocity of the cells are strikingly similar during the event; velocities of these storm elements are in the order of $70 \mathrm{~km} \mathrm{~h}^{-1}$ for most of the event.

The composite effects of storm structure, storm evolution, and orographic enhancement of precipitation on the regional distribution of precipitation are illustrated in Figs. 11a,b through the relationship between storm total rainfall and maximum 30-min rainfall rates (Fig. 11a) and storm total rainfall and the fraction of storm total produced by heavy rainfall rates (30-min rainfall rates exceeding $20 \mathrm{~mm} \mathrm{~h}^{-1}$ ) (Fig. 11b). Rainfall intensity $>20 \mathrm{~mm} \mathrm{~h}^{-1}$ exceeds the $20 \%$ quantile of the cumulative distribution of saturated hydraulic conductivity values collected in the higher portions of the Fella basin by using a Guelph permeameter. Even though point values of saturated hydraulic conductivity may be affected by large spatial variability, this value suggests the potential for significant infiltration excess runoff.
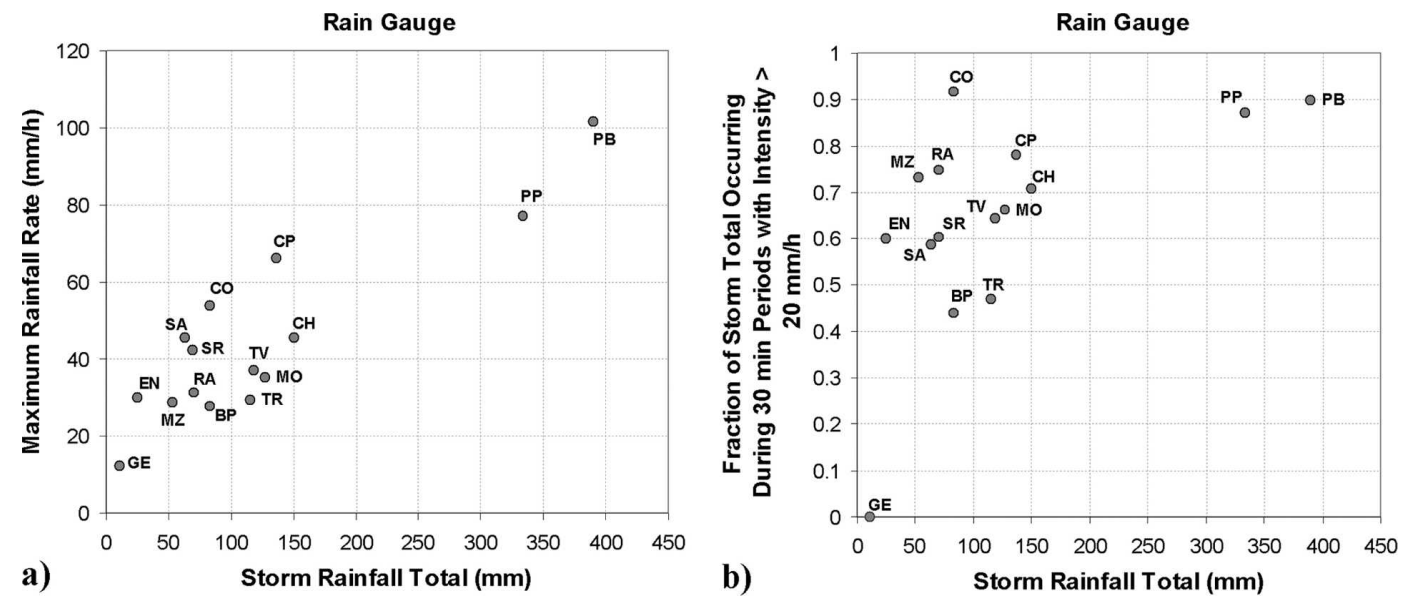

FIG. 11. Precipitation analysis: (a) storm total rainfall and maximum 30-min rainfall rates; (b) storm total rainfall and the fraction of storm total produced by heavy rainfall rates (30-min rainfall rates exceeding $20 \mathrm{~mm} \mathrm{~h}^{-1}$ ). 
TABLE 1. Characteristics of the surveyed river sections and of the corresponding drainage basins.

\begin{tabular}{|c|c|c|c|}
\hline Basin & River system & $\begin{array}{c}\text { Basin } \\
\text { area }\left(\mathrm{km}^{2}\right)\end{array}$ & Type of information available \\
\hline Uqua at Ugovizza & Fella (Tagliamento) & 23.9 & Peak estimate (post-event survey) \\
\hline Fella at Pontebba & Fella (Tagliamento) & 164.5 & $\begin{array}{l}\text { River stage time series; stage-discharge relationship } \\
\text { (post-event survey) }\end{array}$ \\
\hline Fella at Dogna & Fella (Tagliamento) & 329.5 & $\begin{array}{l}\text { River stage time series; stage-discharge relationship } \\
\text { (post-event survey) }\end{array}$ \\
\hline Raccolana at Raccolana & Fella (Tagliamento) & 61.6 & $\begin{array}{l}\text { River stage time series; stage-discharge relationship } \\
\text { (post-event survey) }\end{array}$ \\
\hline Resia at Borgo Povici & Fella (Tagliamento) & 102.1 & $\begin{array}{l}\text { River stage time series; stage-discharge relationship } \\
\text { (post-event survey) }\end{array}$ \\
\hline Fella at Moggio Udinese & Fella (Tagliamento) & 623.1 & $\begin{array}{l}\text { River stage time series; stage-discharge relationship } \\
\text { (post-event survey) }\end{array}$ \\
\hline Tagliamento at Venzone & Tagliamento & 1843.4 & River stage time series \\
\hline R. del Lago at Cave Predil & Slizza (Drava) & 40.6 & $\begin{array}{l}\text { River stage time series; stage-discharge relationship } \\
\text { (post-event survey) }\end{array}$ \\
\hline Slizza at Tarvisio & Slizza (Drava) & 73.1 & $\begin{array}{l}\text { River stage time series; stage-discharge relationship } \\
\text { (post-event survey) }\end{array}$ \\
\hline Vorderbergbach & Gail (Drava) & 26.9 & $\begin{array}{l}\text { Peak estimates and estimation of runoff volumes (post-event } \\
\text { survey; Moser 2003) }\end{array}$ \\
\hline
\end{tabular}

In these figures one should note that only the two rain gauges located in $\mathrm{PP}$ and $\mathrm{PB}$ were under the influence of the major convective precipitation band. This can be noted in Fig. 11a, where the two rain gauges are characterized by highest rainfall accumulation and rates. This shows clearly that the central convective band was associated with the intensification of rainband precipitation in the upper watersheds, due to orographic enhancement, leading to the largest rainfall rates and accumulations. The lowest rainfall accumulations and rates occurred in portions of the region that were not under the influence of the convective bands.

The quasi-stationary character of the storm is outlined in Fig. 11b, where most of the stations (with the exception of those with low rainfall accumulations) are characterized by high values of the fraction of storm total rainfall with 30 -min intensity $>20 \mathrm{~mm} \mathrm{~h}^{-1}$. Rainfall rates greater than $20 \mathrm{~mm} \mathrm{~h}^{-1}$ accounted for $>70 \%$ of the rainfall measured for half of the stations, including some of those measuring 50-100-mm rainfall accumulations.

\section{Analyses of flood response}

Rainfall produced by the August 2003 storm resulted in severe flooding throughout the Fella River basin. The storm produced catastrophic flooding at drainage areas up to $80-90 \mathrm{~km}^{2}$, with dominance of debris floods (Slaymaker 1988) at basin scale up to some tens of kilometers. These debris floods were essentially extreme streamflows with large quantities of muds, rocks, and debris, including woody debris. The extremely in- tense rainfall of August 2003 storm provided not only additional materials by creating new and reactivating old landslides but also high peak streamflows required for occurrence of debris floods. According to Tropeano et al. (2004), the debris and sediment mass mobilized and deposited downslope and over the valley bottom may be roughly estimated at 1 million cubic meters. Fluvial impact of the August 2003 flood includes significant stream widening and incision.

Stream gauge data and observations from post-event surveys, combined with hydraulic modeling, were used to examine hydrologic response to the storm. Stream gauge data were available at eight sites (Fig. 4 and Table 1). Two out of the eight sites belong to the Slizza River system, which is a tributary of the Drava and of the Danube, while the other six belong to the Fella River system. Almost all these gauges are located either close or at bridge crossing sites, where measurements are taken by means of ultrasound sensors. Hydraulic modeling, combined with surveys of the postflood river section geometry and data about preflood geometry, was used to derive stage-discharge relationships at these river sections. Furthermore, hydraulic modeling was used to estimate peak discharges based on surveyed high watermarks and postflood channel geometry at another three sites (including the site at the outlet of Uqua basin; Table 1) and to confirm the estimates at the gauged sections. Information on runoff volumes and flood peak concerning the Vorderberg River (located in Austria, bordering the Uqua basin, on the northern side of the mountain range) were obtained from Moser (2003). It was not feasible to extend indi- 
rect flood peak estimation to basins with drainage area less than $20 \mathrm{~km}^{2}$, due to the difficulties in establishing the actual flood channel geometry in river reaches subject to substantial erosion and/or deposition. Furthermore, the character of the flow process places essential limitations to traditional procedures for indirect peak estimation, which are likely to be flawed in case of debris flows.

Twenty-two local residents, mostly located close to the Uqua River basin and its fan, were interviewed about the severity of the storm and such factors as wind and timing of rainfall. Comments on the rate of stream rise and timing of peak stage were also noted.

\section{a. The flood response model}

Hydrologic response to August 2003 storm is examined by using a simple spatially distributed hydrologic model [Kinematic Local Excess Model (KLEM); Cazorzi and Dalla Fontana 1992]. The distributed model is based on availability of raster information of the landscape topography and of the soil and vegetation properties. In the model, the SCS-Curve Number (SCS-CN) procedure (U.S. Department of Agriculture 1986) is applied on a grid-by-grid way for the spatially distributed representation of runoff generating processes, while a simple description of the drainage system response (Da Ros and Borga 1997; Giannoni et al. 2003) is used to represent runoff propagation.

The general SCS-CN runoff equation is

$$
\begin{array}{lll}
q=\frac{\left(P-I_{a}\right)^{2}}{\left(P-I_{a}+S\right)} & \text { for } & P \geq I_{a}, \\
q=0 & \text { for } & P<I_{a},
\end{array}
$$

where $q(\mathrm{~mm})$ is the direct runoff depth, $P(\mathrm{~mm})$ is the event rainfall depth, $I_{a}(\mathrm{~mm})$ is an "initial abstraction" or event rainfall required for the initiation of runoff, and $S(\mathrm{~mm})$ is a site storage index defined as the maximum possible difference between $P$ and $q$ as $P \rightarrow \infty$. $P-I_{a}$ is also called "effective rainfall," or $P_{e}$. The SCS-CN method can be applied by specifying a single parameter called the curve number, $\mathrm{CN}$, which is function of the hydrologic soil-cover complex and ranges in principles from 1 to 100 . The spatial distribution of the $\mathrm{CN}$ values was obtained from previous investigations on the study area (Cazorzi and Bincoletto 2005). Following Ponce and Hawkins (1996), the value of S for a given soil is related to the curve number as

$$
S=C\left(\frac{100}{C N}-1\right),
$$

where $C$ is a calibration parameter $(\mathrm{mm})$, called infiltration storativity. The use of the parameter $C$ allows one to use the spatial distribution of $\mathrm{CN}$ values, which represents an input data in this work, and to simulate correctly, at the same time, the observed flood water balance. In the original SCS-CN equation the value of $C$ is $254 \mathrm{~mm}$ and the initial abstraction is specified as a percentage of $S$. Given the exceptionally low soil moisture initial conditions, the proportionality factor between $I_{a}$ and $S$ (herewith called $X$ ) was considered as a further parameter in this study.

The distributed runoff propagation procedure is based on the identification of drainage paths and requires the characterization of hillslope paths and channeled paths. We used a channelization support area $\left(A_{s}\right)\left(\mathrm{km}^{2}\right)$, which is considered constant at the subbasin scale, to distinguish hillslope elements from channel elements. Discharge at any location along the river network is represented by

$$
Q(t)=\int_{A} q[t-\tau(x), x] d x,
$$

where $A\left(\mathrm{~km}^{2}\right)$ indicates the area draining to the specified outlet location, $q(t, x)$ is the runoff at time $t$ and location $x$, and $\tau(x)$ is the routing time from $\mathrm{x}$ to the outlet of the basin specified by the region A. The routing time $\tau(x)$ is defined as

$$
\tau(x)=\frac{L_{h}(x)}{v_{h}}+\frac{L_{c}(x)}{v_{c}},
$$

where $L_{h}(x)$ is the distance from the generic point $\mathrm{x}$ to the channel network following the steepest descent path, $L_{c}(x)$ is the length of the subsequent drainage path through streams down to the watershed outlet, and $v_{h}$ and $v_{c}\left(\mathrm{~m} \mathrm{~s}^{-1}\right)$ are two invariant hillslope and channel velocities, respectively.

The model includes also a linear conceptual reservoir for base flow modeling, whose structure was kept invariant over all basins. The reservoir input is provided by the infiltrated rate computed based on the CN-SCS method; the method is applied at the subbasin scale.

The model framework is based on six calibration parameters: the channelization support area $\left(A_{s}\right)$, two kinematic parameters $\left(v_{h}\right.$ and $\left.v_{c}\right)$, the parameter $C$ required for the calibration of the SCS-CN procedure, and the parameter $I_{a}$ required for the specification of the initial abstraction. The model was implemented at 15-min time step and using a 20-m grid size cell for the description of landscape morphology and soil properties.

\section{b. Flood response properties}

The KLEM model was applied to the nine different basins of the Fella and Slizza River system for which 
TABLE 2. Rainfall and runoff for the surveyed basins (NA: not available).

\begin{tabular}{|c|c|c|c|c|c|c|}
\hline Basin & $\begin{array}{l}\text { Total rain } \\
\quad(\mathrm{mm})\end{array}$ & $\begin{array}{l}\text { Total runoff } \\
\quad(\mathrm{mm})\end{array}$ & $\begin{array}{l}\text { Peak discharge } \\
\qquad\left(\mathrm{m}^{3} \mathrm{~s}^{-1}\right)\end{array}$ & $\begin{array}{l}\text { Unit peak discharge } \\
\qquad\left(\mathrm{m}^{3} \mathrm{~s}^{-1} \mathrm{~km}^{-2}\right)\end{array}$ & $\begin{array}{l}\text { Runoff ratio } \\
(-)\end{array}$ & $\begin{array}{l}\text { Lag time } \\
\text { (h) }\end{array}$ \\
\hline Uqua at Ugovizza & 287 & NA & 200 & 8.36 & NA & 2.0 \\
\hline Fella at Pontebba & 247 & 49.4 & 680 & 4.13 & 0.18 & 2.0 \\
\hline Fella at Dogna & 237 & - & 805 & 2.44 & - & 2.0 \\
\hline Raccolana at Raccolana & 96 & 3.8 & 27 & 0.43 & 0.04 & 4.0 \\
\hline Resia at Borgo Povici & 71 & 6.4 & 54 & 0.53 & 0.09 & 3.0 \\
\hline Fella at Moggio Udinese & 189 & 28.3 & 1290 & 2.1 & 0.15 & 3.5 \\
\hline Tagliamento at Venzone & 110 & NA & NA & NA & NA & 3.5 \\
\hline R. del Lago at Cave Predil & 122 & 7.3 & 15 & 0.37 & 0.06 & 1.5 \\
\hline Slizza at Tarvisio & 132 & 9.2 & 38 & 0.52 & 0.07 & 2.0 \\
\hline Vorderbergbach & 260 & 65.0 & 125 & 4.65 & 0.25 & NA \\
\hline
\end{tabular}

data and observations are available for model calibration and verification.

These data are summarized in Table 2 to permit water balance and response time analysis. Data reported in Table 2 show that there are systematic differences among the surveyed basins. Maximum rainfall accumulations were recorded along the Fella main stream down to Dogna and on the Vordergergbach. These four basins are all located under the central convective rainband. Much of the lower accumulations were received by Resia and Raccolana, which were only partially located under a rainband. The runoff ratio ranges between 0.25 for $260 \mathrm{~mm}$ total rainfall to less than 0.1 for the smallest rainfall totals. The low values of runoff ratios point out the impact of the dry antecedent soil moisture conditions.

The strong influence of the initial conditions is confirmed by results obtained from the water balance analysis of the 22 June 1996 flood (Table 3). This flood, for which only rain gauge data were available for rainfall estimation, was characterized by two very intense consecutive storm episodes and a total duration of $54 \mathrm{~h}$. Initial conditions were much wetter than for the August 2003 flood. These two characteristics translate into much more uniform rainfall totals over the various subbasins (with totals ranging from 220 to almost $300 \mathrm{~mm}$ ) and larger runoff ratios, ranging from 0.34 to 0.52 . It should be noted that estimates reported in Table 3 are obtained through application of the rainfall-runoff model, which was verified on the Venzone observed hydrograph. At that time, postflood surveys were not carried out for indirect peak estimation.

The large influence of the initial soil moisture condition on the August 2003 flash flood is not unexpected, due to the combination of the exceptionally dry summer 2003 and high soil moisture capacity characterizing the study area. In this region, soil moisture storage capacity is closely linked to the presence of densely fractured bedrock and of relatively thick surficial deposits, developed from colluvium and underlained by carbonate rocks (Mosetti 1983). The ratio of daily discharge which is exceeded $90 \%$ of the time to the mean daily flow, $Q_{90} / Q_{A}$, ranges between 0.31 to 0.46 in the upper Tagliamento basin, with values ranging between 0.33 to 0.36 for the Fella basin. These are relatively high values and correspond to large groundwater storage. The flood response in the Fella basin suggests that the combination of high soil moisture storage capacity and low antecedent soil moisture conditions is an important factor determining land surface response to extreme rainfall.

In addition to nonlinearities in the storm event water balance, there are also pronounced heterogeneities in the hydraulics of basin response. Lag time, obtained as the time difference between the discharge peak and the rainfall mass center, is comparatively very short for the basins with large rainfall accumulations, irrespective of basin area, whereas it is relatively large for the watersheds characterized by low storm totals. This pattern reflects the systematic decrease of basin response with increasing the rainfall accumulation. Two major factors controlling this process are the expansion of stream network to unchanneled topographic elements during the flood and the increase of flow velocity with discharge.

TABLE 3. Rainfall and runoff for the surveyed basins for the 22 Jun 1996 flood event (NA: not available).

\begin{tabular}{lccc}
\hline \multicolumn{1}{c}{ Basin } & $\begin{array}{c}\text { Total rain } \\
(\mathrm{mm})\end{array}$ & $\begin{array}{c}\text { Total runoff } \\
(\mathrm{mm})\end{array}$ & $\begin{array}{c}\text { Runoff } \\
\text { ratio }(-)\end{array}$ \\
\hline Uqua at Ugovizza & 257 & NA & NA \\
Fella at Pontebba & 266 & 122 & 0.46 \\
Fella at Dogna & 277 & 130 & 0.47 \\
Raccolana at Raccolana & 275 & 143 & 0.52 \\
Resia at Borgo Povici & 281 & 133 & 0.48 \\
Fella at Moggio Udinese & 293 & 145 & 0.50 \\
Tagliamento at Venzone & 220 & 75 & 0.34 \\
R. del Lago at Cave Predil & 249 & 118 & 0.47 \\
Slizza at Tarvisio & 225 & 102 & 0.46 \\
Vorderbergbach & NA & NA & NA \\
\hline
\end{tabular}


TABLE 4. KLEM parameterization, stratified according to basin-average precipitation accumulation.

\begin{tabular}{ccccccc}
\hline $\begin{array}{c}\text { Cumulated precipitation } \\
P(\mathrm{~mm})\end{array}$ & $A_{\mathrm{th}}\left(\mathrm{km}^{2}\right)$ & $V_{c}\left(\mathrm{~m} \mathrm{~s}^{-1}\right)$ & $V_{h}\left(\mathrm{~m} \mathrm{~s}^{-1}\right)$ & $(x)(-)$ & $I_{a}(\mathrm{~mm})$ & $C(\mathrm{~mm})$ \\
\hline$P<100$ & 0.05 & 2.5 & 0.03 & 0.03 (Raccolana) & $43-61$ & $1626.0($ Raccolana) \\
& & & & 0.1 (Resia) & 80.4 (Resia) \\
$100 \leq P<200$ & 0.03 & 4.5 & 0.04 & 0.2 & $50-117$ & 508.0 \\
$P \geq 200$ & 0.01 & 5.0 & 0.2 & 0.4 & $142-169$ & 254.0 \\
\hline
\end{tabular}

The KLEM model parameters were estimated simultaneously over multiple catchments by means of a combination af manual and automatic calibration to minimize an integrated normalized integrated rootmean-square error over the flood hydrograph. The basin-average values of the spatially variable $\mathrm{CN}$ parameter given as input to the model ranges between 41 and 49 across the various basins, with larger values for the upper basins and lower values for the lower portions of the Fella watershed. This pattern is due to the development of bare rock surfaces on the upper portions of the Fella. The degree of nonlinearity arising from the available data could not be reproduced by the flood response model with a basin-invariant parameterization. The rainfall spatial distribution was the most important factor preventing the use of an invariant parameterization. Actually, the rainfall and runoff values reported in Table 2 can be easily reproduced by using $S=350 \mathrm{~mm}$ and $I_{a}=0.2 S$, which means by using spa- tially uniform values for both rainfall and $\mathrm{CN}$, as noted by a reviewer.

Three different parameter sets were identified, stratified according to the basin-average rainfall accumulation (Table 4). Figures 13a-c show model results for the basins of Uqua at Ugovizza, Fella at Pontebba, and Fella at Moggio Udinese. Results concerning flood peak and time to peak are reported in Table 5, and point out the reasonable accuracy of the simulations provided by the hydrological model.

Some patterns in the model parameters may be noted in Table 4. For the basins characterized by the largest rainfall accumulations, the extracted river network reflects a smaller support area, with an elaboration of the drainage network into unchannelized swales during the extreme event. For these basins, the modeled overland flow velocities $\left(0.2 \mathrm{~m} \mathrm{~s}^{-1}\right)$ that reproduce observed timing and magnitude of the flood peaks exceed the upper end of the range of values $\left(0.003-0.14 \mathrm{~m} \mathrm{~s}^{-1}\right)$ reported

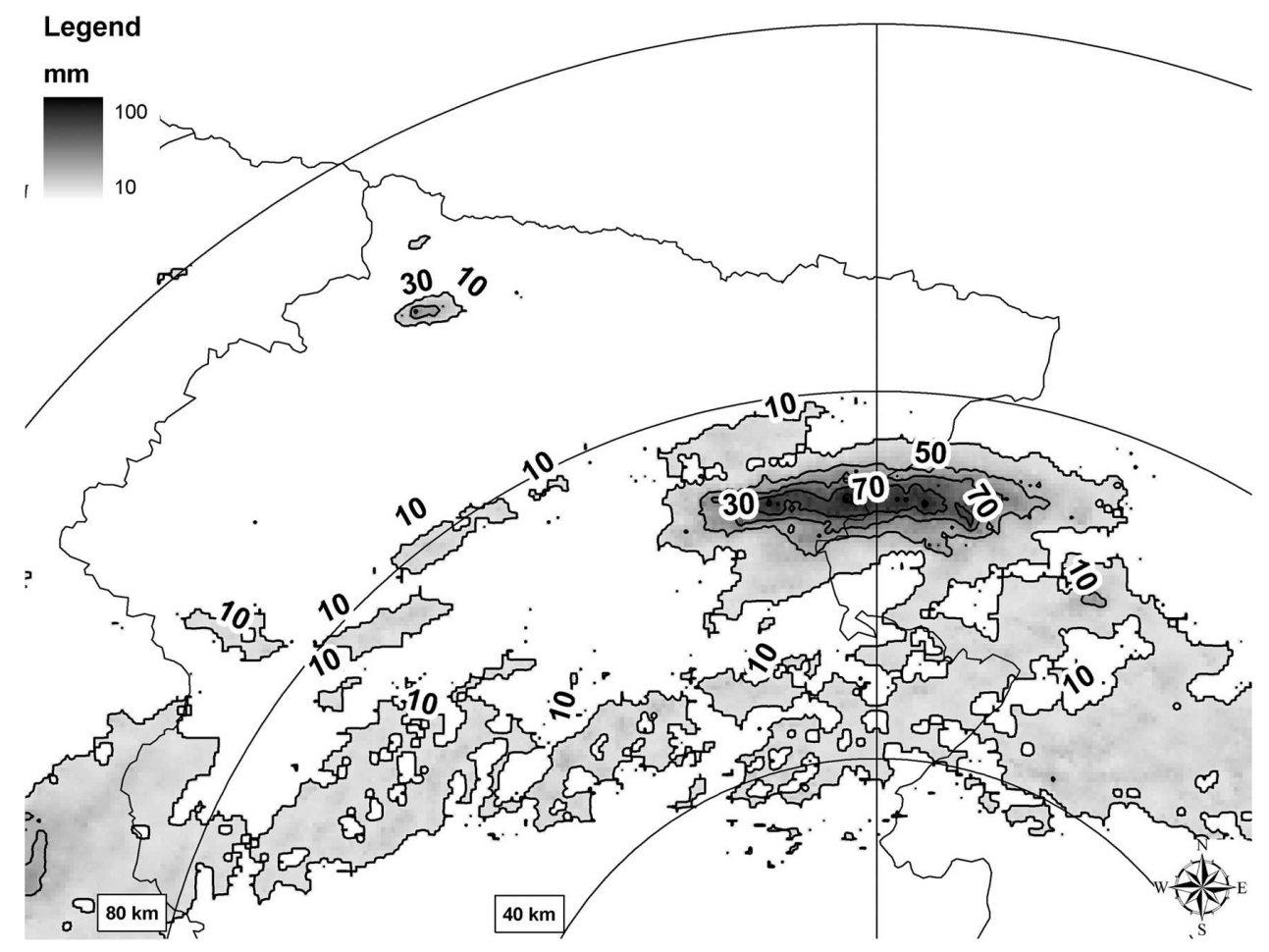

FIG. 12. Storm total rainfall (mm) for 28 Aug 2003. 

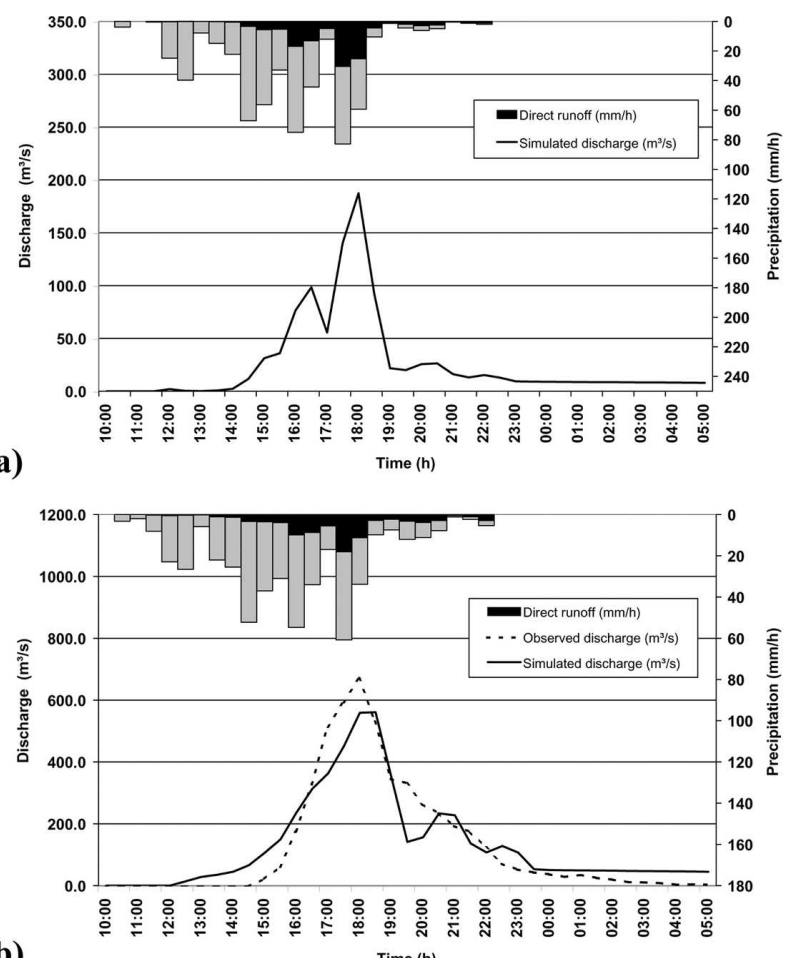

b)

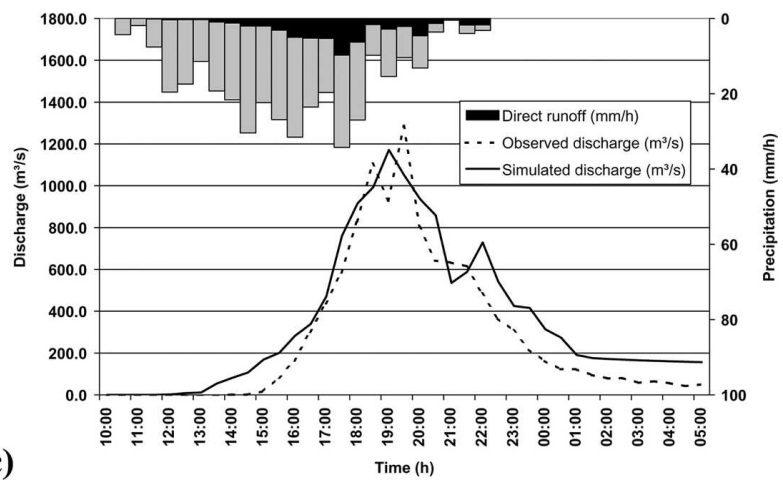

FIG. 13. Results of KLEM application for the three nested Fella basins closed at (a) Ugovizza (Uqua), (b) Pontebba, and (c) Moggio Udinese.

by Dunne (1978). Since the model overland flow is spatially and temporally constant, it must account for sheet flow as well as concentrated overland flow in areas not specified as channels. For this extreme event, overland flow velocities were likely greater than typical due to steep slopes and large amount of sheet flow.

As reported in section 2, on 28 August 2003, the day before the flood, a localized convective storm generated almost $100-\mathrm{mm}$ precipitation on areas of the lefthand tributaries of the Fella River system. The precipitation was focused on the basins of Resia (32 mm of cumulated basin-averaged rainfall) and Raccolana (12 $\mathrm{mm}$ of cumulated rainfall). It is likely that this localized thunderstorm introduced elements of spatial variability in the pattern of soil moisture initial conditions. For instance, the runoff ratio appears to be higher for the Resia basin, which was affected by larger previous precipitation amounts, than for the nearby Raccolana basin for similar rainfall totals. However, the runoff ratio is very low for both basins and in the same range of orther basins with similar rainfall amount. The initial soil moisture conditions were probably dry enough to mitigate the influence of spatial heterogeneity in the antecedent precipitation. On the other hand, uncertainties in both rainfall and runoff observed amounts propagate in large uncertainties in the model parameters, particularly for these basins.

\section{c. Influence of space-time precipitation variability at the catchment scale}

To characterize the influence of temporal and spatial variability of rainfall on flood response, we utilized 30min, 1-km radar rainfall fields to compute the following quantities:

1) the mean rainfall rate over the catchment at time $t$ during the storm, $M(t)$;

2) the fractional coverage of the basin by rainfall rates exceeding $20 \mathrm{~mm} \mathrm{~h}^{-1}, F(t)$;

3) the normalized time distance of rainfall from the basin outlet, $D(t)$; and

4) the normalized dispersion of rainfall, $S_{\mathrm{NOR}}(t)$.

The mean rainfall rate and fractional coverage time series provide basic information on rainfall mass balance and distribution of rainfall rates over the catchment. They do not provide information on the spatial distribution of rainfall relative to the basin network structure, however. The drainage network, as represented by the routing time $\tau(x)$, provides a natural metric for analyzing the spatial distribution of rainfall, as shown previously by Zhang et al. (2001), Smith et al. (2005), and Skøien et al. (2006). The routing time incorporates both geometric and kinematic properties in its determination. The routing time is therefore a more convenient measure with respect to purely geometric values, such as the distance, when runoff propagates through the network at spatially variable velocities.

The normalized time distance at time $t, D(t)$, is a function of the rainfall field $R(t, x)$ and the routing time $\tau(x)$. It is defined as the ratio of the rainfall-weighted centroid routing time $D_{1}(t)$ and the mean routing time $d_{\text {mean }}$. The time distance $D_{1}(t)$ can be represented as

$$
D_{1}(t)=|A|^{-1} \int_{A} w(t, y) \tau(y) d y,
$$


TABLE 5. Simulated and estimated flood peaks and errors in time to peak (NA: not available).

\begin{tabular}{lccc}
\hline \hline \multicolumn{1}{c}{ Basin } & $\begin{array}{c}\text { Simulated peak discharge } \\
\left(\mathrm{m}^{3} \mathrm{~s}^{-1}\right)\end{array}$ & $\begin{array}{c}\text { Estimated peak discharge } \\
\left(\mathrm{m}^{3} \mathrm{~s}^{-1}\right)\end{array}$ & $\begin{array}{c}\text { Error in time to peak } \\
(\mathrm{h})\end{array}$ \\
\hline Uqua at Ugovizza & 187.0 & 200 & 0 \\
Fella at Pontebba & 560.5 & 680 & +0.5 \\
Fella at Dogna & 1053.9 & 805 & 0 \\
Raccolana at Raccolana & 29.6 & 27 & -0.5 \\
Resia at Borgo Povici & 60.2 & 54 & 0 \\
Fella at Moggio Udinese & 1170.8 & 1290 & -0.5 \\
Tagliamento at Venzone & 1303.1 & $\mathrm{NA}$ & +1.0 \\
R. del Lago at Cave Predil & 21.7 & 15 & 0 \\
Slizza at Tarvisio & 39.2 & 38 & 0 \\
\hline
\end{tabular}

where $A$ is the spatial domain of the drainage basin and the weight function $w(t, y)$ is given by

$$
w(t, y)=\frac{R(t, y)}{|A|^{-1} \int_{A} R(t, y) d y} .
$$

Values of $D(t)$ close to 1 reflect a rainfall distribution either concentrated close to the mean time distance or homogeneous, with values less than 1 indicating that rainfall is distributed near the basin outlet, and values greater than 1 indicating that rainfall is distributed toward the periphery of the drainage basin.

The rainfall-weighted flow time-distance dispersion is given by

$$
S(t)=\left\{\int_{A} w(t, y)\left[\tau(y)-D_{1}(t)\right]^{2} d y\right\}^{0.5} .
$$

The dispersion for uniform rainfall is defined by

$$
S_{1}=\left\{\int_{A}\left[\tau(y)-d_{\text {mean }}\right]^{2} d y\right\}^{0.5},
$$

and the normalized dispersion is given by

$$
S_{\mathrm{NOR}}(t)=\frac{S(t)}{S_{1}} .
$$

Values of $S_{\mathrm{NOR}}(t)$ close to 1 reflect a uniform-like rainfall distribution, with values less than 1 indicating that rainfall is characterized by a unimodal peak, and values greater than 1 indicating cases of multimodal rainfall peaks close and far from the basin outlet.

Results are reported for the nested Fella basins of Rio Uqua at Ugovizza, Fella at Pontebba, and Fella at Moggio Udinese (Fig. 14). Note that the watershed of Fella at Moggio includes two important left-hand tributaries: Raccolana and Resia (Fig. 4). Values of mean routing time and standard deviation are reported in Table 6 for the three basins.
Flood-producing rainfall for the Uqua and the Fella at Pontebba was concentrated over a period of $4 \mathrm{~h}$, lasting from 1430 to 1830 LST. Rainfall peaked from 1900 to 2100 LST over Raccolana and Resia, thus extending the storm period over the Fella basin at Moggio for $2 \mathrm{~h}$ and half. Three hourly peak values of basinaveraged rainfall can be recognized for the Uqua basin and the Fella at Pontebba. These peaks, which were synchronous over the two basins, occurred at 1430, 1600 , and 1730 LST, with two hiatuses of $30 \mathrm{~min}$, and increased with time, from 60 to $71 \mathrm{~mm}$, over the Uqua. This condition is a typical trigger for diffused landsliding and debris flow, as documented by Montgomery et al. (2002) and Borga et al. (2002).

The fractional coverage of heavy rainfall (greater than $20 \mathrm{~mm} \mathrm{~h}^{-1}$ ) displays three peaks: the first at 1230 LST, the second for the period from 1430 to 1630 LST, and the last at 1800 LST. For the Fella at Moggio an increasing trend can be recognized (up to 1800 LST) in the peaks of fractional coverage.

Despite the large variability in rainfall over the Fella basin, the "conditional" distribution of routing times, given the spatial rainfall distribution, was close to the distribution of routing times in the uniform rainfall case, particularly for the Uqua and the Fella at Pontebba. For the Uqua, normalized time distance and dispersion are virtually unchanged from uniform rainfall case. Moving from Uqua to Pontebba and then to Moggio, a downbasin storm motion can be recognized, as reflected in decreasing values of normalized time distance. This is in contrast to the fast upstream motion of the convective cells, and partially explains why the flood peak was recorded at the same time (around 1800 LST) at Ugovizza and Pontebba. At Moggio two peaks were recorded: the first at 1830 LST and the second at 1930 LST. The first is associated with the flood response from the nearby Aupa basin (according to interviews collected from local residents), whereas the second peak is associated to the upstream Fella River 


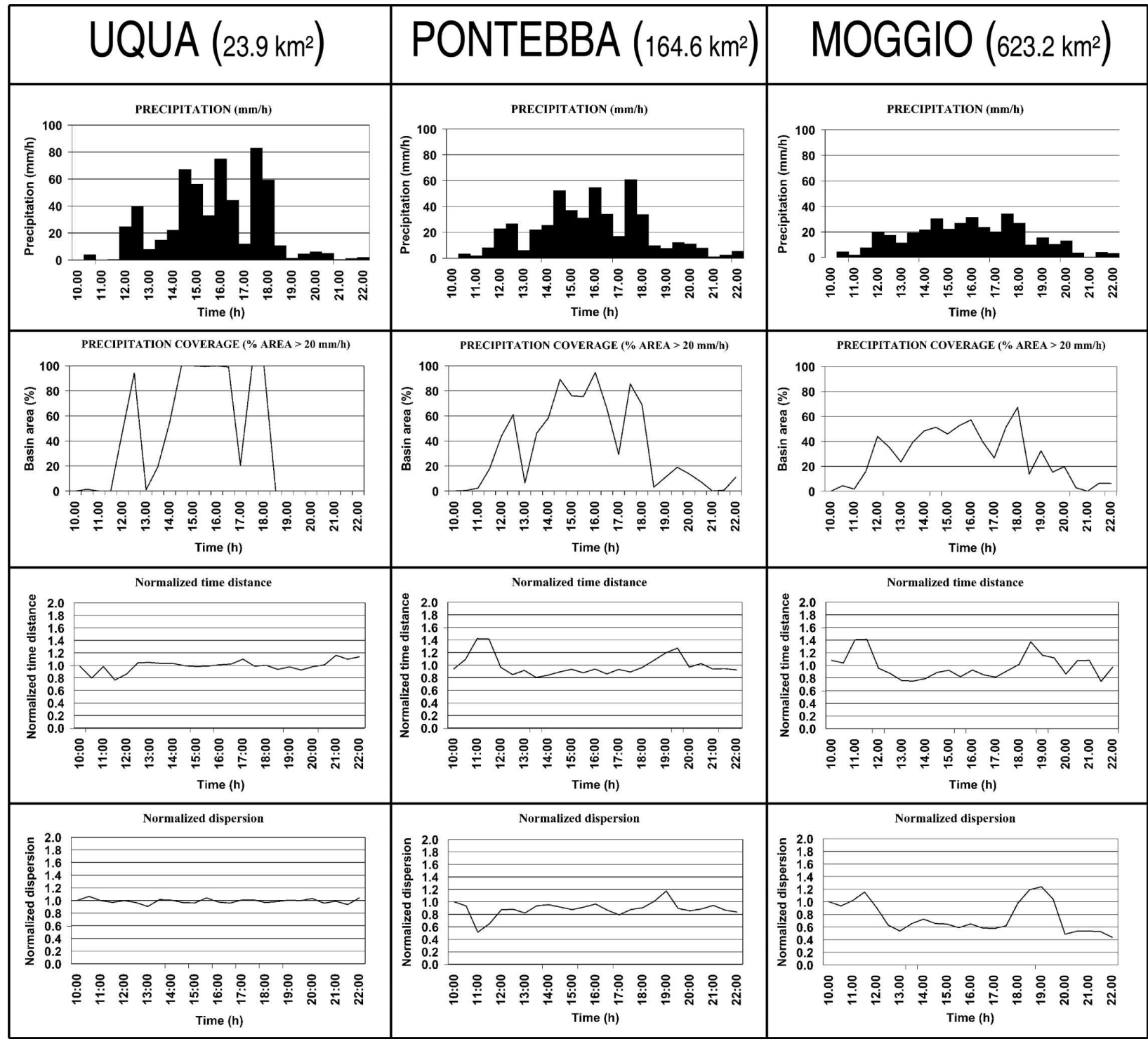

FIG. 14. Precipitation analyses by using time series of precipitation intensity, coverage (for precipitation intensity $>20 \mathrm{~mm} \mathrm{~h}$ ), and normalized time distance, for the three nested Fella basins closed at Ugovizza, Pontebba, and Moggio Udinese.

response. Our runoff model is unable to accurately portray the specific response time of each basin. For this reason, the double peak was not reproduced in the simulation (Fig. 13c).

The increase of normalized time distance and of dispersion at Moggio after 1800 LST is related the storm event over Raccolana and Resia, which are characterized by a relatively slow response.

\section{d. Scale-dependent flood response}

A fundamental research topic in hydrology is to understand the physical basis of observed scaling statistics relating flood peaks with their drainage areas (Furey and Gupta 2005). Observational flash flood studies and model analyses of hydrologic response illustrate how storm structure and evolution translate into scale-

TABle 6. Mean travel time and standard deviation for Uqua at Ugovizza, Fella at Pontebba, and Fella at Moggio.

\begin{tabular}{lrcc}
\hline \hline \multicolumn{1}{c}{ Basin } & $\begin{array}{r}\text { Area } \\
\left(\mathrm{km}^{2}\right)\end{array}$ & $\begin{array}{c}\text { Mean travel } \\
\text { time (h) }\end{array}$ & $\begin{array}{c}\text { Std dev } \\
\text { of travel } \\
\text { time (h) }\end{array}$ \\
\hline Uqua at Ugovizza & 23.9 & 0.46 & 0.18 \\
Fella at Pontebba & 164.5 & 1.01 & 0.39 \\
Fella at Moggio Udinese & 623.1 & 2.52 & 1.3 \\
\hline
\end{tabular}


ENVELOPE CURVE AND MEAN RAINFALL

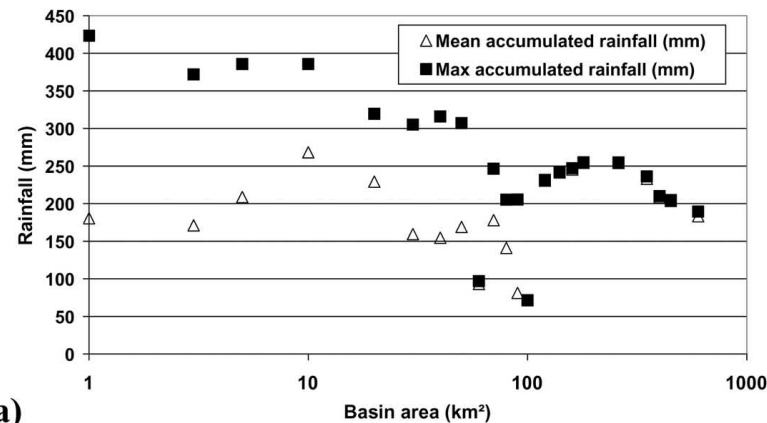

a)

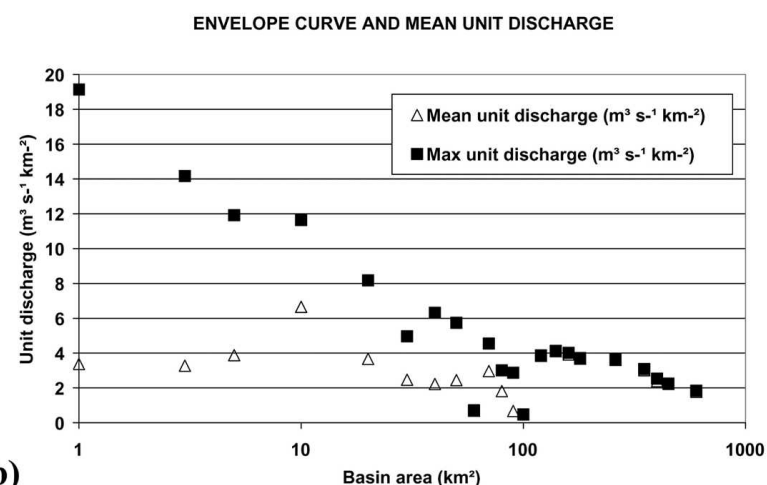

b)

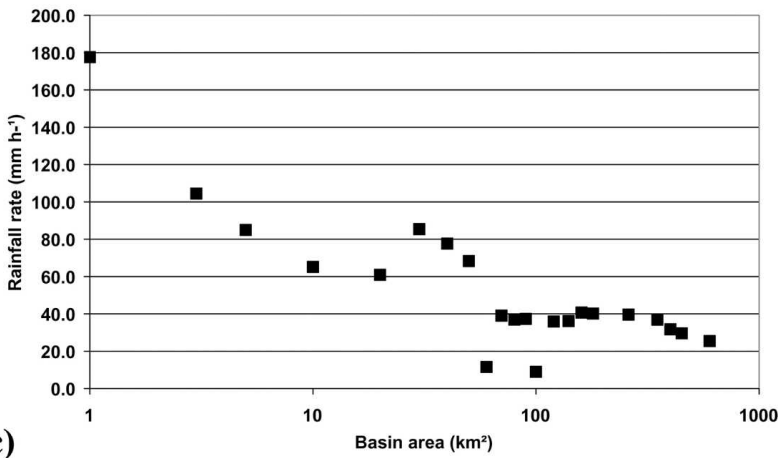

FIG. 15. The relationship between (a) accumulated rainfall, (b) peak unit discharges, and (c) maximum rainfall rate averaged over basin response time, with drainage area. Unit discharges are derived from the hydrological model simulations.

dependent flood response. Based on observations and model analyses, peak discharges were computed at regular intervals along stream network. For each of these model gaging stations, the upstream drainage area, the peak discharge and the rainfall accumulations were computed (Zhang et al. 2001) (Figs. 15a,b). Figure 15 a shows the relationship of the rainfall accumulations with upslope basin area, whereas Fig. 15b shows the same relationship for peak unit discharge. To understand how the space-time structure of precipitation controls scale-dependent flood response, the maximum intensity averaged over the basin time response was computed for each basin included in the envelope of peak unit discharge (Fig. 15c).

It is possible to identify two regions in the pattern of maximum unit peak discharges: (a) basin scale ranging from 1 to $90 \mathrm{~km}^{2}$, with unit discharges decreasing from 19 to $5 \mathrm{~m}^{3} \mathrm{~s}^{-1} \mathrm{~km}^{-2}$; (b) basin scale ranging from 90 to $600 \mathrm{~km}^{2}$, with smaller unit discharges, decreasing from 4 to $2 \mathrm{~m}^{3} \mathrm{~s}^{-1} \mathrm{~km}^{-2}$. The first region reproduces the shape of the central convective band, with a mean width of $9 \mathrm{~km}$. The region of peak storm total accumulation in the upper portion of the Fella River basin (Uqua and Pontebbana River basins) is the location of the largest model discharges at small drainage area. Results reported in Fig. 15c show that a major factor controlling the shape of the scale dependency of peak unit discharges is the reduction with basin area of the maximum rainfall intensity averaged over basin response time. The pattern of the scale dependent averaged precipitation intensity reproduces the two regions identified for the scale-dependent flood response (from 1 to $90 \mathrm{~km}^{2}$, and from 90 to $600 \mathrm{~km}^{2}$ ) and the different scaling with area within the two regions.

\section{Conclusions}

There are six principal observations from our work.

1) The August 2003 storm system, which produced record storm accumulations, flood peaks, and impressive geomorphic changes, provides a model for mesoscale convective systems that are likely responsible for the majority of flash flood peaks in the upper Tagliamento River basin. Extreme rainfall from the August 2003 storm was produced by quasistationary convective banded structures. Some of the bands persisted in the same locations for the duration of the event. The steadiness of these rainbands led to highly variable precipitation accumulations and runoff. The characteristic spatial scale of the convective bands is around $9 \mathrm{~km}$, which results in a dominant spatial scale for rainfall accumulation and flooding of around $100 \mathrm{~km}^{2}$.

2) Antecedent soil moisture distribution appears to have played an important role in flood response. Measured peak discharges were large, but not as exceptional as implied by the measured rainfall. The exceptionally dry summer season of 2003, combined with the high soil moisture storage capacity that characterizes the basins in the upper Tagliamento watershed, resulted in low runoff ratios and emphasized the nonlinearity of the flood response. These 
findings are confirmed by comparison with a previous extreme flood occurred on 22 June 1996.

3) Pronounced contrasts in flood response between different basins of varying catchment size are related to (a) effect of the spatial organization of the banded convection, (b) contrasting fractional coverage of rainfall following from basin size and structure, and (c) differential response due to the highly nonlinear relationship between rainfall and runoff. An important source of nonlinearity is related to the strong dependency of basin response time to storm accumulation.

4) The storm event response can be reasonably well reproduced with a simple distributed hydrologic model, using high-resolution rainfall observations. However, application of the model to the case study required stratification of parameterization according to precipitation accumulation at the subbasin scale. The degree of nonlinearity arising from the available data could not be reproduced by the flood response model with invariant parameterization.

5) Model analyses of hydrologic response for the August 2003 storm illustrate the role of storm structure, motion, and evolution for scale-dependent flood response. A major factor controlling the shape of the scale dependency of peak unit discharges is the spatial extent of the major convective band.

6) For the August 2003 flood, postflood interviews, field observations, and surveys were important sources of information. The combination of detailed radar rainfall estimates, readily available GIS data, hydrologic and hydraulic modeling, postflood surveys, and interviews with local residents allowed us to generate a much more complete picture of the storm and flood environment than would otherwise be available on ungauged basins.

Acknowledgments. This work was supported by the European Community's Sixth Framework Programme through the grant to the budget of the Integrated Project FLOODsite, Contract GOCE-CT-2004-505420 and in part by the STREP project HYDRATE, Contract GOCE 037024 and by the PRIN project 2005072101. The Regional Meteorological Observatory of FriuliVenezia-Giulia is thanked for making the radar dataset available and for the assistance in data analysis. Valuable comments from Michela Dini (Regione Autonoma Friuli Venezia Giulia) and Lorenzo Marchi (CNRIRPI, Padova) greatly improved the manuscript. In addition, the writers extend their thanks to three unknown reviewers for making important suggestions that improved the text.

\section{REFERENCES}

Bacchi, B., R. Ranzi, and M. Borga, 1996: Statistical characterization of spatial patterns of rainfall cells in extratropical cyclones. J. Geophys. Res., 101, 26 277-26 286.

Bechini, R., E. Gorgucci, G. Scarchilli, and S. Dietrich, 2002: The operational weather radar of Fossalon di Grado (Gorizia, Italy): Accuracy of reflectivity and differential reflectivity measurements. Meteor. Atmos. Phys., 79, 275-284.

Berenguer, M., G. W. Lee, D. Sempere-Torres, and I. Zawadzki, 2002: A variational method for attenuation correction of radar signal. Proc. Second European Conf. on Radar Meteorology (ERAD), Delft, Netherlands, European Meteorological Society, 11-16.

Borga, M., E. N. Anagnostou, and E. Frank, 2000: On the use of real-time radar rainfall estimates for flood prediction in mountainous basins. J. Geophys. Res., 105 (D2), 2269-2280.

_ G. Dalla Fontana, and F. Cazorzi, 2002: Analysis of topographic and climatic control on rainfall-triggered shallow landsliding using a quasi-dynamic wetness index. J. Hydrol., 268, 56-71.

Casty, C., H. Wanner, J. Luterbach, J. Esper, and R. Böhm, 2005: Temperature and precipitation variability in the European Alps since 1500. Int. J. Climatol., 25, 1855-1880.

Cazorzi, F., and G. Dalla Fontana, 1992: L'utilizzo dei sistemi informativi geografici nello studio idrologico di bacino (in Italian). Quaderni di Idronomia Montana, 12, 83-115.

__ , and L. Bincoletto, 2005: Modellazione dei processi idrologici. La prevenzione del rischio idrogeologico nei piccoli bacini montani della regione: Esperienze e conoscenze acquisite con il progetto CATCHRISK (in Italian). Convegno finale del Progetto CATCHRISK, Udine, Italy, INTERREG IIIB, 45-74.

Ceschia, M., S. Micheletti, and R. Carniel, 1991: Rainfall over Friuli Venezia Giulia: High amounts and strong geographical gradients. Theor. Appl. Climatol., 43, 175-180.

Cucchi, F., C. Piano, E. Marinetti, G. Massari, S. Oberti, and L. Zini, 2000: Studies for the realization of the hydrogeological map of Friuli-Venezia Giulia. Ipogea, 3, 57-71.

Da Ros, D., and M. Borga, 1997: Use of digital elevation model data for the derivation of the geomorphologic instantaneous unit hydrograph. Hydrol. Processes, 11, 13-33.

Deganutti, A. M., L. Marchi, and M. Arattano, 2000. Rainfall and debris-flow occurrence in the Moscardo basin (Italian Alps). Debris-Flow Hazard Mitigation: Mechanics, Prediction, and Assessment, G. F. Wieczorek and N. D. Naeser, Eds., Balkema, 67-72.

Delrieu, G., H. Andrieu, and J. D. Creutin, 2000: Quantification of path-integrated attenuation for X- and C-Band weather radar systems operating in Mediterranean heavy rainfall. J. Appl. Meteor., 39, 840-850.

—, and Coauthors, 2005: The catastrophic flash-flood event of 8-9 September 2002 in the Gard region, France: A first case study for the Cévennes-Vivarais Mediterranean Hydrometeorological Observatory. J. Hydrometeor., 6, 34-52.

Dunne, T., 1978: Field studies of hillslope flow processes. Hillslope Hydrology, M. J. Kirkby, Ed., John Wiley, 227-293.

Furey, P. R., and V. J. Gupta, 2005: Effects of excess rainfall on the temporal variability of observed peak-discharge power laws. Adv. Water Resour., 28, 1240-1253.

Gaume, E., M. Livet, and M. Desbordes, 2003: Study of the hydrological processes during the Avène River extraordinary 
flood (south of France): 6-7 October 1997. Phys. Chem. Earth, 28, 263-267.

$\longrightarrow,-, \ldots$, and J. P. Villeneuve, 2004: Hydrological analysis of the river Aude, France, flash flood on 12 and 13 November 1999. J. Hydrol., 286, 135-154.

Giannoni, F., J. A. Smith, Y. Zhang, and G. Roth, 2003: Hydrologic modeling of extreme floods using radar rainfall estimates. Adv. Water Resour., 26, 195-200.

Hicks, N. S., J. A. Smith, A. J. Miller, and P. A. Nelson, 2005: Catastrophic flooding from an orographic thunderstorm in the central Appalachians. Water Resour. Res., 41, W12428, doi:10.1029/2005WR004129.

Hitschfeld, W. F., and J. Bordan, 1954: Errors inherent in the radar measurement of rainfall at attenuating wavelengths. $J$. Meteor., 11, 58-67.

Marchi, L., and V. D'Agostino, 2004: Estimation of debris-flow magnitude in the eastern Italian Alps. Earth Surf. Processes Landforms, 29, 207-220.

—, M. Arattano, and A. M. Deganutti, 2002: Ten years of debris-flow monitoring in the Moscardo Torrent (Italian Alps). Geomorphology, 46, 1-17.

Montgomery, D. R., W. E. Dietrich, and J. T. Heffner, 2002: Piezometric response in shallow bedrock at CB1: Implications for runoff generation and landsliding. Water Resour. Res., 38, 1274, doi:10.1029/2002WR001429.

Moser, J., 2003: Hochwasser am Vorderberger Wildbach (in German). Amt der Kärntner Landesregierung, Abteilung 18 Wasserwirtschaft, $15 \mathrm{pp}$.

Mosetti, F., 1983: Sintesi sull'idrologia del Friuli-Venzia Giulia, Quaderni dell'Ente Tutela Pesce del Friuli-Venzia Giulia (in Italian). Rivista di Limnologia, 6, 1-295.

Ogden, F. L., H. O. Sharif, S. U. S. Senarath, J. A. Smith, M. L. Baeck, and J. R. Richardson, 2000: Hydrologic analysis of the Fort Collins, Colorado flash flood of 1997. J. Hydrol., 228, $82-100$.

Pellarin, T., G. Delrieu, G. M. Saulnier, H. Andrieu, B. Vignal, and J. D. Creutin, 2002: Hydrologic visibility of weather radar systems operating in mountainous regions: Case study for the Ardèche catchment (France). J. Hydrometeor., 3, 539555 .
Ponce, V. M., and E. R. H. Hawkins, 1996: Runoff curve number: Has it reached maturity? J. Hydrol. Eng., 1, 11-19.

Querini, R., 1977: L’influenza del terremoto sulla torrenzialità nei bacini montani del Friuli (in Italian). Annali dell'Accademia Italiana di Scienze Forestali, 26, 139-185.

Skøien, J. O., R. Merz, and G. Bloeschl, 2006: Top-kriging: Geostatistics on stream networks. Hydrol. Earth Syst. Sci., 10, 277-287.

Slaymaker, O., 1988: The distinctive attributes of debris torrents. Hydrol. Sci., 33, 567-573.

Smith, J. A., M. L. Baeck, M. Steiner, and A. J. Miller, 1996: Catastrophic rainfall from an upslope thunderstorm in the central Appalachians: The Rapidan storm of 27 June 1995. Water Resour. Res., 32 (10), 3099-3113.

,-- K. L. Meierdiercks, P. A. Nelson, A. J. Miller, and E. J. Holland, 2005: Field studies of the storm event hydrologic response in an urbanizing watershed. Water Resour. Res., 41, W10413, doi:10.1029/2004WR003712.

Stedinger, J. R., R. M. Vogel, and E. Foufoula-Georgiu, 1992: Frequency analysis of extreme events. Handbook of Hydrology, D. R. Maidment, Ed., McGraw-Hill, 18.1-18.66.

Tropeano, D., L. Turconi, and S. Sanna, 2004: Debris flows triggered by the 29 August 2003 cloudburst in Val Canale, eastern Italian Alps. Proc. Int. Symp. INTERPRAEVENT 2004, Riva del Garda, Italy, 121-132.

U.S. Department of Agriculture, 1986: Urban hydrology for small watersheds. U.S. Department of Agriculture Tech. Release $55,164 \mathrm{pp}$.

Villi, V., G. Caleffa, G. Gatto, and G. Mori, 1986: Distribuzione spazio temporale delle piogge intense nel Triveneto- cartografia (in Italian). Quaderno di Ricerca, 7, C.N.R and Regione Veneto, 1-444.

Ward, J. V., K. Tockner, P. J. Edwards, J. Kollmann, G. Bretschko, A. M. Gurnell, G. E. Petts, and B. Rossaro, 1999: A reference system for the Alps: The "Fiume Tagliamento." Regul. Rivers, 15, 63-75.

Wood, E. F., M. Sivapalan, and K. Beven, 1990: Similarity and scale in catchment storm response. Rev. Geophys., 28, 1-18.

Zhang, Y., J. A. Smith, and M. L. Baeck, 2001: The hydrology and hydrometeorology of extreme floods in the Great Plains of eastern Nebraska. Adv. Water Resour., 24, 1037-1050. 